

\section{Net Zero Energy Military Installations: A Guide to Assessment and Planning}

Samuel Booth, John Barnett, Kari Burman, Josh Hambrick and Robert Westby

Prepared under Task No. IDOD.1010
Technical Report NREL/TP-7A2-48876

August 2010

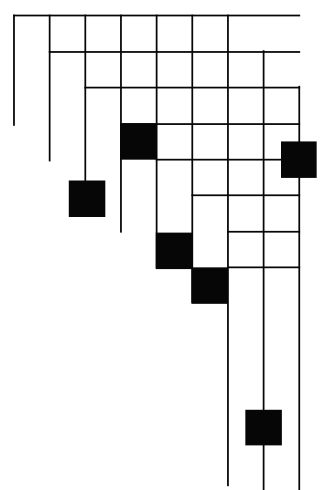




\section{NOTICE}

This report was prepared as an account of work sponsored by an agency of the United States government. Neither the United States government nor any agency thereof, nor any of their employees, makes any warranty, express or implied, or assumes any legal liability or responsibility for the accuracy, completeness, or usefulness of any information, apparatus, product, or process disclosed, or represents that its use would not infringe privately owned rights. Reference herein to any specific commercial product, process, or service by trade name, trademark, manufacturer, or otherwise does not necessarily constitute or imply its endorsement, recommendation, or favoring by the United States government or any agency thereof. The views and opinions of authors expressed herein do not necessarily state or reflect those of the United States government or any agency thereof.

Available electronically at http://www.osti.gov/bridge

Available for a processing fee to U.S. Department of Energy and its contractors, in paper, from:

U.S. Department of Energy

Office of Scientific and Technical Information

P.O. Box 62

Oak Ridge, TN 37831-0062

phone: 865.576 .8401

fax: 865.576 .5728

email: mailto:reports@adonis.osti.gov

Available for sale to the public, in paper, from:

U.S. Department of Commerce

National Technical Information Service

5285 Port Royal Road

Springfield, VA 22161

phone: 800.553 .6847

fax: 703.605.6900

email: orders@ntis.fedworld.gov

online ordering: http://www.ntis.gov/ordering.htm 


\section{Table of Contents}

Abstract

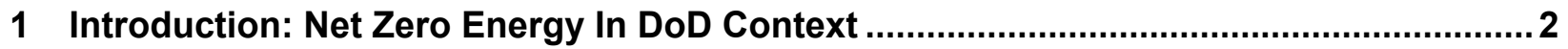

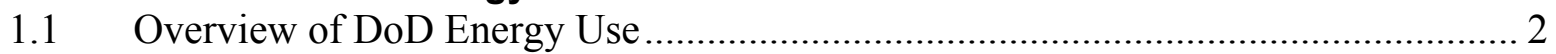

1.2 Energy Strategies for DoD Installations: Key Considerations ……………............... 3

$1.3 \quad$ Net Zero Energy Installation Concept .................................................................... 5

$1.4 \quad$ Net Zero Energy Assessment and Planning Approach ................................................ 7

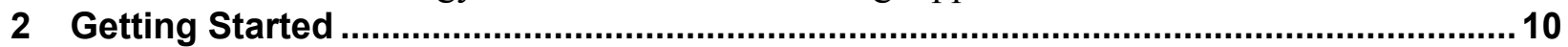

2.1 Making the Case and Securing Leadership Support.................................................. 10

2.2 Establishing a Net Zero Energy Installation Team ................................................. 10

2.3 Defining the Project Boundaries ............................................................................ 11

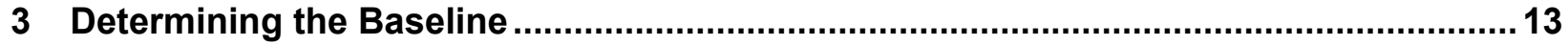

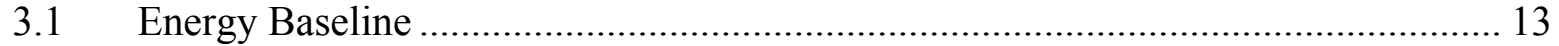

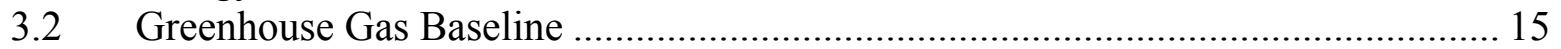

4 Reducing Energy Demand by Engaging People .......................................................... 18

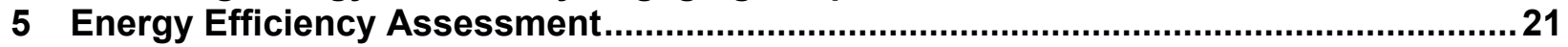

6 Renewable Energy and Load Reduction Assessment .................................................26

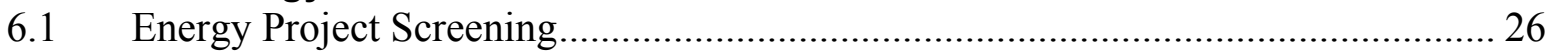

6.2 Detailed Technical Assessment ........................................................................... 27

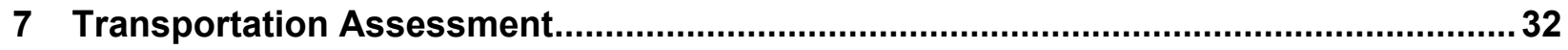

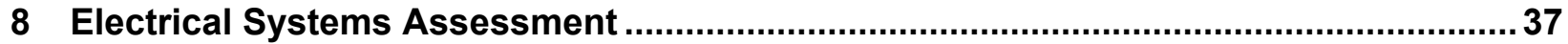

$8.1 \quad$ Grid-Connected Operations: Impact Assessment .................................................. 37

8.2 Islanded Microgrid Assessment................................................................................. 39

9 Energy Project and Implementation Recommendations..............................................43

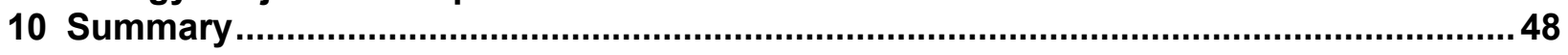




\section{Table of Figures}

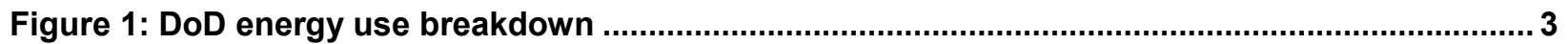

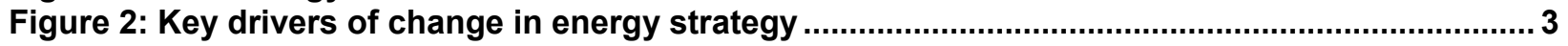

Figure 3: Flow diagram of net zero energy assessment and implementation...................................9

Figure 4: Flow diagram of the baseline process....................................................................... 14

Figure 5: Common GHG emission sources and related scopes ....................................................... 16

Figure 6: Main steps in an energy awareness campaign........................................................... 19

Figure 7: Sample energy awareness campaign material .............................................................. 20

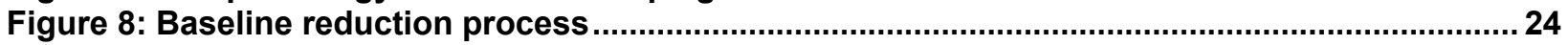

Figure 9: Solar pool heating system and solar photovoltaic system at Camp Pendleton, CA......... 28

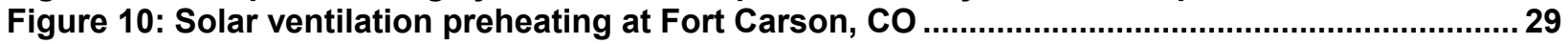

Figure 11: Wind turbines at a U.S. Navy installation, San Clemente Island, CA .............................. 29

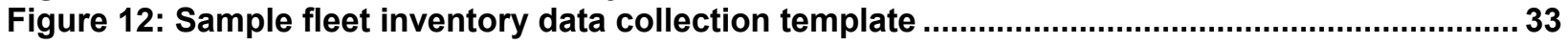

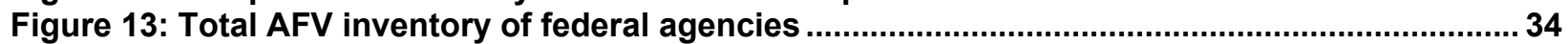

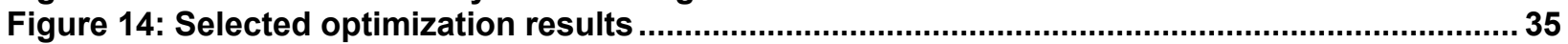

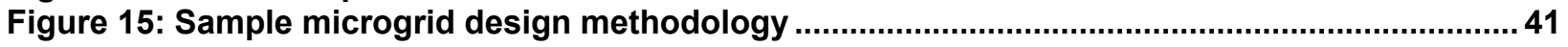

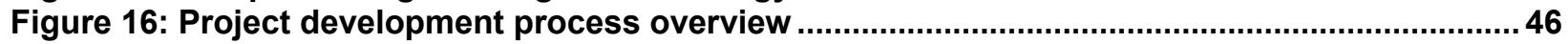

\section{Acronyms and Abbreviations}

\begin{tabular}{|c|c|c|c|}
\hline $\begin{array}{l}\text { AFV } \\
\text { Btu }\end{array}$ & $\begin{array}{l}\text { Alternative fuel vehicle } \\
\text { British thermal unit }\end{array}$ & HVAC & $\begin{array}{l}\text { Heating, ventilating, and air } \\
\text { conditioning }\end{array}$ \\
\hline CNG & Compressed natural gas & LED & Light-emitting diode \\
\hline CSP & Concentrating solar power & LNG & Liquefied natural gas \\
\hline \multirow[t]{2}{*}{ DEW } & Distributed Engineering & LPG & Liquefied petroleum gas \\
\hline & Workstation & MCAS & Marine Corps Air Station \\
\hline DoD & U.S. Department of Defense & NEPA & National Environmental Policy Act \\
\hline DOE & U.S. Department of Energy & NEV & Neighborhood electric vehicle \\
\hline EERC & Energy Escalation Rate Calculator & NREL & National Renewable Energy \\
\hline EJV & Energy joint venture & & Laboratory \\
\hline E.O. & Executive Order & NZEI & Net Zero Energy Installation \\
\hline \multirow[t]{2}{*}{ EPA } & U.S. Environmental Protection & O\&M & Operations and maintenance \\
\hline & Agency & OSD & Office of the Secretary of Defense \\
\hline ESPC & Energy savings performance & PPA & Power purchase agreement \\
\hline EUI & Energy use index & REC & Renewable energy certificate \\
\hline EUL & Enhanced use lease & RFI & Request for Information \\
\hline \multirow[t]{2}{*}{ FEMP } & Federal Energy Management & RFP & Request for Proposal \\
\hline & Program & RMPA & Rocky Mountain Power Area \\
\hline FFV & Flex fuel vehicle & SAM & Solar Advisory Model \\
\hline FY & Fiscal year & SROPTTC & Site, Resource, Off-take, Permits, \\
\hline GHG & Greenhouse gas & & Technology, Team, Capital \\
\hline HEV & Hybrid electric vehicle & UESC & Utility energy services contract \\
\hline HOMER & $\begin{array}{l}\text { Hybrid Optimization Model for } \\
\text { Electric Renewables }\end{array}$ & WECC & $\begin{array}{l}\text { Western Electricity Coordinating } \\
\text { Council }\end{array}$ \\
\hline
\end{tabular}




\section{Abstract}

The U.S. Department of Defense (DoD) has long recognized the strategic importance of energy to its mission, and is working to reduce energy consumption as well as to enhance energy selfsufficiency by drawing on local clean energy sources. A joint initiative formed between DoD and the U.S. Department of Energy (DOE) in 2008 to address military energy use led to a task force to examine the potential for net zero energy military installations, which would produce as much energy on-site from renewable energy generation, or through the on-site use of renewable fuels, as they consume in buildings, facilities, and fleet vehicles.

This report presents an assessment and planning process to examine military installations for net zero energy potential. Net Zero Energy Installation (NZEI) assessment offers a systematic framework to analyze energy projects at installations while balancing other site priorities such as mission, cost, and security.

The assessment begins with a baseline of current electrical, thermal, and transportation fleet energy consumption. Energy conservation and efficiency projects are explored to identify economic approaches to minimizing energy demand. Renewable energy generation technologies are then examined for their potential to meet the remaining energy loads, and fleet fuel use is analyzed for opportunities to switch to alternative fuels or electric vehicles. This assessment leads to recommendations for energy efficiency, renewable energy, and transportation energy projects. Prior to final technology recommendations, the installation's electrical system is assessed to verify interconnection capacity and to determine the potential for islanded microgrid operations. ${ }^{1}$ Project implementation options are selected, and high-order project financials are developed to demonstrate cost savings and financial return of the recommended projects. The assessment output is designed to give installation decision makers a clear understanding of the opportunities for energy projects and the next steps needed to implement them.

Assessing military installations for net zero energy potential using this template as a guide will lead to energy strategies tailored to individual installation requirements. While installations will vary in their ability to achieve net zero status, the disciplined process detailed in this report will lead to minimized energy demand and maximum leveraging of local renewable energy resources, all supporting achievement of DoD and national energy goals.

\footnotetext{
${ }^{1}$ Islanded microgrid operations constitute the ability to operate all or part of an installation independent of the larger electrical grid. All power required for operations is produced on the installation and generation plus loads are controlled on the installation.
} 


\section{Introduction: Net Zero Energy In DoD Context}

In 2008, DoD and DOE defined a joint initiative to address military energy use by identifying specific actions to reduce energy demand and increase use of renewable energy on DoD installations. A task force comprised of representatives from the Office of the Secretary of Defense (OSD), the four military services, DOE's Federal Energy Management Program (FEMP), and the National Renewable Energy Laboratory (NREL) was established. In light of DoD priorities, early attention was given to the possibility of net zero energy military installations; that is, installations that would meet their energy needs with local renewable resources. Marine Corps Air Station (MCAS) Miramar was selected by the task force to be the prototype installation for net zero energy assessment and planning, on the basis of Miramar's strong history of energy advocacy and extensive track record of successful energy projects.

NREL's role was to perform a comprehensive, first-of-its-kind assessment of MCAS Miramar's potential to achieve net zero energy status, including energy project recommendations, and then to develop a template based on this work that could be employed at other military installations. The template was developed into this assessment and planning guide. As background for the implementation guidance of subsequent chapters, this chapter provides an overview of DoD energy use, the net zero energy installation concept, and the assessment and planning process.

\subsection{Overview of DoD Energy Use}

$\mathrm{DoD}$ is the largest energy consumer in the U.S. government. Present energy use patterns impact DoD global operations by constraining freedom of action and self-sufficiency, demanding enormous economic resources, and putting many lives at risk in associated logistics support operations in deployed environments. There appear to be many opportunities to more effectively meet DoD energy requirements through a combination of human actions, energy efficiency technologies, and renewable energy resources. DoD's corporate hierarchy offers advantages in the implementation of these opportunities at speed and scale: the military has often been a market leader in the adoption of new technologies and complex systems. The present focus of DoD leaders on exploring improvements to energy provision and use in the department's operations - at home and abroad - is timely.

In fiscal year (FY) 2008 DoD consumed 889 trillion site-delivered Btu (more than used by entire nations such as Denmark or Israel) and spent on the order of $\$ 20$ billion on energy. The majority of DoD energy consumption is fossil fuel based (coal, oil, natural gas, or electricity produced from these), often from foreign sources. DoD accounts for about $1.8 \%$ of total U.S. petroleum consumption and $0.4 \%$ of the world's consumption. A summary of DoD energy use is shown in figure 1 . The focus of this report is the $26 \%$ of energy used in goal subject buildings, ${ }^{2}$ buildings exempted from these mandates, and fleet vehicles. Tactical fuel use is not considered at this time. $^{3}$

\footnotetext{
${ }^{2}$ Federal buildings are subject to mandated energy efficiency reductions under the National Energy Conservation Policy Act (NECPA) and Executive Order (E.O.) 13423. Some buildings are exempt from these requirements. Guidelines for exempting buildings can be found at $\mathrm{http}$ ://www1.eere.energy.gov/femp/pdfs/exclusion_criteria.pdf. ${ }^{3}$ Alternative fuels are in development and testing. Also, tactical fuel use can be reduced through reduction in tactical system use (for example, in favor of simulator-based training), and through application of energy-saving technologies (for example, skin coatings for aircraft and ships, improvements in aerodynamic/hydrodynamic design, and hybrid drive systems for ground vehicles).
} 


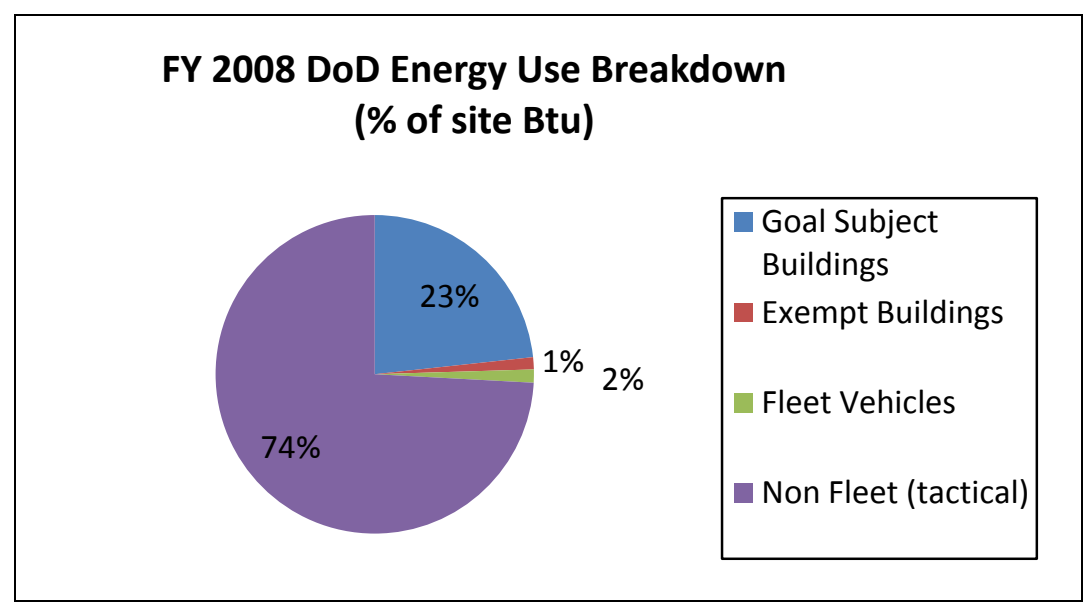

Figure 1: DoD energy use breakdown ${ }^{4}$

An overview of many of the drivers of change for military energy projects can be seen in figure 2 .

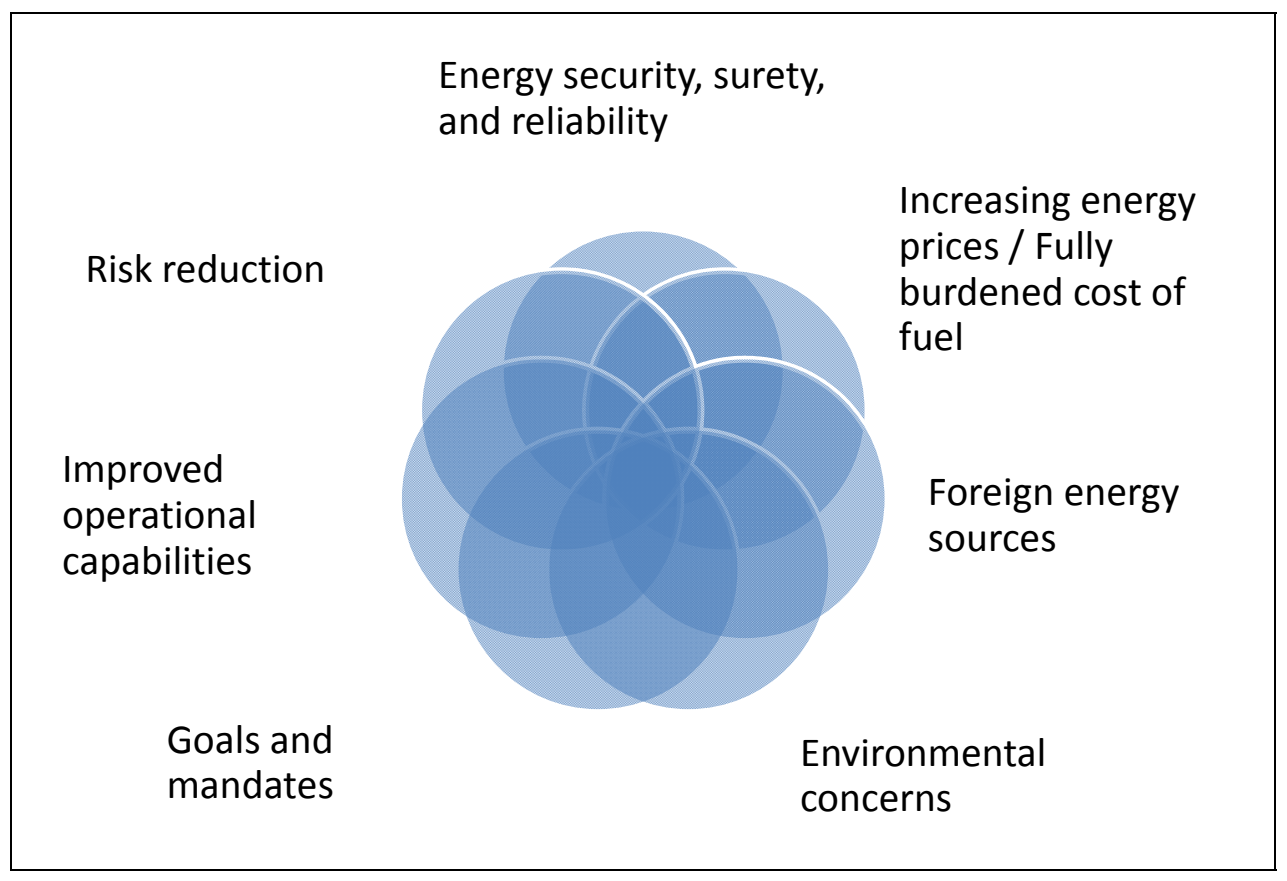

Figure 2: Key drivers of change in energy strategy

\subsection{Energy Strategies for DoD Installations: Key Considerations}

A NZEI assessment is a framework for a military installation to develop a holistic and systematic energy strategy. An installation's energy strategy should reflect a number of constraints and considerations:

- Mission compatibility: Mission accomplishment is the top priority for installations. Even if attractive by other measures, incompatibility with the installation's mission

\footnotetext{
${ }^{4}$ Department of Defense Annual Energy Management Report Fiscal Year 2008, January 2009, http://www.acq.osd.mil/ie/energy/library/DoDenergymgmtrpt08.pdf.
} 
eliminates any energy-related proposal. Wind turbines sited near a runway are one example of an energy technology incompatible with the flying mission at many military installations (due to radar interference by turbine blades).

- Security: Energy security, surety and reliability, as well as overall physical security of the site, must be maintained or enhanced by the installation's energy system. For example, a biomass-fueled power system may be unsuited to some sites due to off-site truck traffic required to bring in fuel. On the other hand, the ability to meet an installation's critical load using on-site renewable sources (e.g., landfill gas, geothermal power, solar energy) in an islanding mode may greatly enhance energy security. This is underscored not only by the threat of malicious activities (e.g., physical or cyber attacks), but also by the possibility of major blackouts such as have occurred in the United States many times in recent decades, of which more are anticipated due to aging electric grid infrastructure, decreased maintenance investment, increasing loads, and the lack of situational awareness on the part of grid operators. ${ }^{5}$ A recent Defense Science Board report stated that critical military missions are at a high risk of failure in the event of an electric grid failure. ${ }^{6}$ The development of on-site energy supplies and smart microgrids, which are part of a net zero energy solution, can reduce this risk, and may become an increasingly important strategic concern.

- Economics: Life-cycle, system-based economic assessment of alternatives should reflect such factors as technological maturity, fuel availability and cost, energy storage requirements, distribution and interconnection arrangements, financing options, federal/state/local incentives, environmental impacts, and costs for operations, maintenance, repair, and parts replacement.

- Agency goals and federal mandates: DoD has a strategic energy plan to reduce consumption, leverage new technologies, drive personnel awareness, and increase energy supply; a primary goal is to achieve 25\% renewable electrical energy use by 2025 . Further, in October 2009 the Secretary of the Navy stated a new goal: by 2020, 50\% of the energy consumed by ships, aircrafts, tanks, shore vehicles, and installations is to come from alternative sources. ${ }^{7}$ Federal mandates presently focus on energy efficiency and renewable energy goals; these are planned to be expanded to include carbon emission targets in the near future.

- Site resources: Energy system siting opportunities (buildings; disturbed or undisturbed land; accessibility) vary among installations, as do local climate, renewable energy resources, and electrical system interconnection opportunities. These all impact energy system design.

- Doctrine, Organization, Training, Material, Leadership \& Education, Personnel and Facilities (DOTMLPF): Over time, holistic change to DoD energy systems, technologies, and practices will involve new doctrine, adjustments to organizations and

\footnotetext{
${ }^{5}$ The Smart Grid, An Introduction, U.S. Department of Energy, No.DE-AC26-04NT41817, Subtask 560.01.04, http://www.oe.energy.gov/DocumentsandMedia/DOE SG Book Single Pages.pdf. Accessed April 2010.

${ }^{6}$ More Fight Less Fuel, Defense Science Board Report, February 2008, http://www.acq.osd.mil/dsb/reports/ADA477619.pdf. Accessed May 2010.

${ }^{7}$ Naval Energy Forum, October 14, 2009, http://osiris.usnwc.edu/pipermail/nwc onlinediscussion/attachments/ 20091119/9d999c42/attachment.obj. Accessed April 1010.
} 
training, new acquisition methodologies, leadership by example, and updates to education systems.

The contribution of a net zero energy assessment to the development of site-specific energy strategies responsive to these constraints is discussed below.

\subsection{Net Zero Energy Installation Concept}

Net zero energy is a concept of energy self-sufficiency based on minimized demand and use of local renewable energy resources. While net zero energy status may not be inherently a high priority for DoD installations, it can serve as a design point well suited to a disciplined exploration of how energy is provided and used. First developed in the context of individual houses, where the challenge is to provide all required energy using on-site renewable resources, the concept has been extended in recent years to communities, campuses, and military installations. In principle, a net zero energy installation should reduce its load through conservation (use what is needed) and energy efficiency (typically the most cost-effective measure that will allow the highest returns per dollar spent), then meet the remaining load through on-site renewable energy. Defining a net zero energy military installation is complicated by the need to consider - in addition to individual buildings, public facilities, and infrastructure - the questions of how to treat energy used for various forms of transportation, and mission-specific energy requirements such as tactical fuel demands.

The original definition of a net zero energy installation adopted by the DoD-DOE task force was, "An installation that produces as much energy on or near the installation, as it consumes in its buildings and facilities." The definition was elaborated in consultation with the task force and MCAS Miramar to include a focus on renewable energy, on-site generation, and fleet fuel use. The following definition is employed in this guide:

"A net zero energy military installation produces as much energy on-site from renewable energy generation or through the on-site use of renewable fuels, as it consumes in its buildings, facilities, and fleet vehicles."

A more detailed explanation of this elaboration and the net zero definition is given below:

- "Net Zero" means that the energy produced on-site over the period of a given year is equal to the installation's energy demand. This implies a connection to a local power grid, which in a sense "banks" the energy. Thus on-site renewable resources, such as solar energy systems, may produce energy greater than that used by the installation during the day, with excess energy fed into the local grid. At night, when the solar system is not producing energy, the installation can pull the previously "banked" energy from the grid to net out the total consumption.

- Energy consumption may be in the form of electricity, steam or hot water, or the direct use of fuel.

- A military installation may be a contiguous area or may comprise separate areas. When assessing the energy of the installation, all activities within the defined boundaries are included regardless of whether their energy is managed by the base energy manager, or paid for by different agencies. 
- A facility is any structure on a military installation that is not a building or fleet vehicle. Examples of facilities include swimming pools and area lighting.

- The task force's willingness to include energy production "on or near the installation" was left open to interpretation. The assessment team focused primarily on the possibilities of on-site energy production, accepting the following forms of energy: energy generated on-site from renewable sources and renewable fuel used on-site. The set of on-site renewable energy sources followed standard DOE practice: commercially available solar (photovoltaic, concentrating solar power, water heating), wind and hydropower systems, and electricity or heat generated from natural gas produced in onsite landfills or by burning the installation's solid waste (waste-to-energy).

○ Renewable fuels include various forms of biomass (wood waste, agricultural byproducts); natural gas produced, for example, from external landfills or as a byproduct of sewage processing; and various renewable transportation fuels (ethanolE85, biodiesel).

- As employed here, the net zero energy concept does not include nonprimary energy imported from off site (e.g., electricity from a local off-site renewable source), or purchases of renewable energy certificates (RECs) - that is, getting credit for renewable energy generation somewhere else in the world. This is in keeping with the net zero energy installation concepts' emphasis on meeting energy needs with local resources.

- The task force definition does not explicitly discuss minimizing the installation's load, an essential first step toward net zero energy status. Load minimization can be accomplished through personnel actions to conserve energy or reduce energy waste, or by identifying approaches to conserve energy without impacting the installation's mission. This also includes the implementation of standard facility energy efficiency technologies to the extent that is economically feasible. These may include heating, ventilating, and air conditioning (HVAC) and lighting upgrades (efficient chillers and boilers, solar ventilation preheat, fluorescent or light-emitting diode [LED] lighting); environmental control systems; plug load reductions; systems generating both electricity and heat (cogeneration systems) where both forms of energy are needed; and building envelope upgrades or design features such as insulation, high-performance windows, and daylighting.

- Installation energy consumption can be measured in several ways. Possible measurement approaches include (adapted from Torcellini et $\mathrm{al}^{8}$ ):

○ Net Zero Site Energy: Energy used by the installation is accounted for at the site, for example, as indicated by building electricity and gas meters. This approach is generally straightforward, but omits transmission losses to bring energy to the site.

○ Net Zero Source Energy: Source energy refers to the primary energy used to generate and deliver the energy to the site, for example by a local utility generation site and transmission system. For transportation fuel, source energy would include a

\footnotetext{
${ }^{8}$ Torcellini et al., "Zero Energy Buildings (ZEB): A Critical Look at the Definition," Golden, Colorado: National Renewable Energy Laboratory, June 2006, http://www.nrel.gov/docs/fy06osti/39833.pdf.
} 
multiplier to account for the energy required to transport the fuel to the fueling station.

○ Net Zero Energy Costs: In this approach, the amount of money the utility pays the installation for renewable energy generated on-site and exported to the grid is compared with the amount the owner pays the utility for energy used over a year.

○ Net Zero Energy Emissions: Here the installation aims to produce on-site at least as much renewable energy as it currently uses from off-site nonrenewable energy sources, on an annual basis, thus offsetting the off-site emissions.

- Net Zero Source Energy was selected as the basis for energy accounting for a NZEI assessment because it is the most representative measure of primary energy consumption.

- Transportation fuel use is included with the following limitations: All transportation fuel consumption data is gathered for the purpose of establishing an installation's total footprint, data permitting. This can include government ground fleet vehicle fuel use, fuel associated with commercial air travel for official business, fuel used in personnel commuting, and tactical fuel use. However, only the government fleet use is further addressed in the NZEI assessment; potential reduction measures include converting to electric vehicles, using electricity generated on-site from renewable sources, or the use of renewable fuels in fleet vehicles.

- DoD's capability to significantly affect energy used in commercial air travel and by commuters is limited to minimizing trips, encouraging carpooling or telecommuting (where possible), or providing electric vehicle charging stations as an incentive for employees to consider electric vehicles when these become widely commercially available, so these categories are not considered. Tactical fuel requirements are not addressed in the assessment because renewable fuel alternatives are not yet commercially available. DoD can (and does) examine training requirements and opportunities to use simulators instead of real tanks/personnel carriers, aircraft, ships and submarines, and explores logistical variations in theater that can further reduce fuel use, but these options are not addressed here.

Again, the net zero energy installation concept can be seen as a useful entry point into an exploration of demand reduction through human action and energy efficiency technology, and meeting the remaining energy needs with local renewable energy resources. Some installations will be able to exceed net zero status to become net energy producers, while others won't be able to approach it. In fact, a net zero goal too strictly applied can lead to solutions that make poor sense from economic or other perspectives. But assessment of a site's net zero potential, combined with consideration of the other constraints identified in section 1.2 of this report, provides a disciplined basis for identifying an optimal energy strategy tailored to the requirements of each site.

\subsection{Net Zero Energy Assessment and Planning Approach}

The Net Zero Energy Assessment and Planning Approach is briefly summarized here and is addressed in detail in the remaining sections of this report. 
1) Initiate the project: Secure leadership support, establish a team representing key stakeholders, define project boundaries, and set a timeline.

2) Establish energy and greenhouse gas baselines: Identify the installation mission, geographic boundaries, relevant energy-related mandates, and any special energy requirements (e.g., reliability, performance in emergency situations, etc.); summarize annual (source) energy used by all identified sources supporting the mission, its type and means of distribution; and become familiar with energy projects already planned on-site. A greenhouse gas (GHG) baseline assessment is included for later comparison with the emissions projected for the recommended future energy system (DoD has not yet released its official GHG emissions reduction goal; however, a preliminary goal has been set internally and a final goal is expected to be released in the near future).

3) Reduce demand through human action: Identify approaches to minimizing wasted energy while maintaining or improving the quality of mission execution by engaging the will, energy, and creativity of installation personnel.

4) Perform an energy efficiency assessment: Identify specific on-site energy efficiency projects and their effect on installation energy consumption.

5) Perform a renewable energy and load reduction assessment: Identify projects exploiting on-site renewable energy for electricity and/or heat production, or employing renewable fuels on-site for electricity and/or heat production.

6) Perform a transportation assessment: Identify projects to reduce and replace fossil fuel use in fleet vehicles.

7) Perform an electrical systems assessment: Identify the impacts of recommended onsite renewable energy projects on the installation's electrical systems. As required by the installation, outline the characteristics of a smart microgrid to support emergency operations in the event of a public grid outage.

8) Make energy project recommendations: Summarize the findings from the preceding efforts to evaluate energy projects and examine implementation options. Then, with reference to broader installation and mission constraints, recommend a set of energy projects. Calculate the extent to which the installation can approach net zero energy status. Demonstrate how the recommended projects, in concert with projects already planned by the installation, can be implemented to produce energy savings, with attention to project timelines, life-cycle economics, and contractual and financing options.

A summary of the NZEI assessment concept can be seen in figure 3. This figure illustrates how installation considerations can be used to develop an optimal energy strategy that leads to project implementation and toward net zero energy status. 


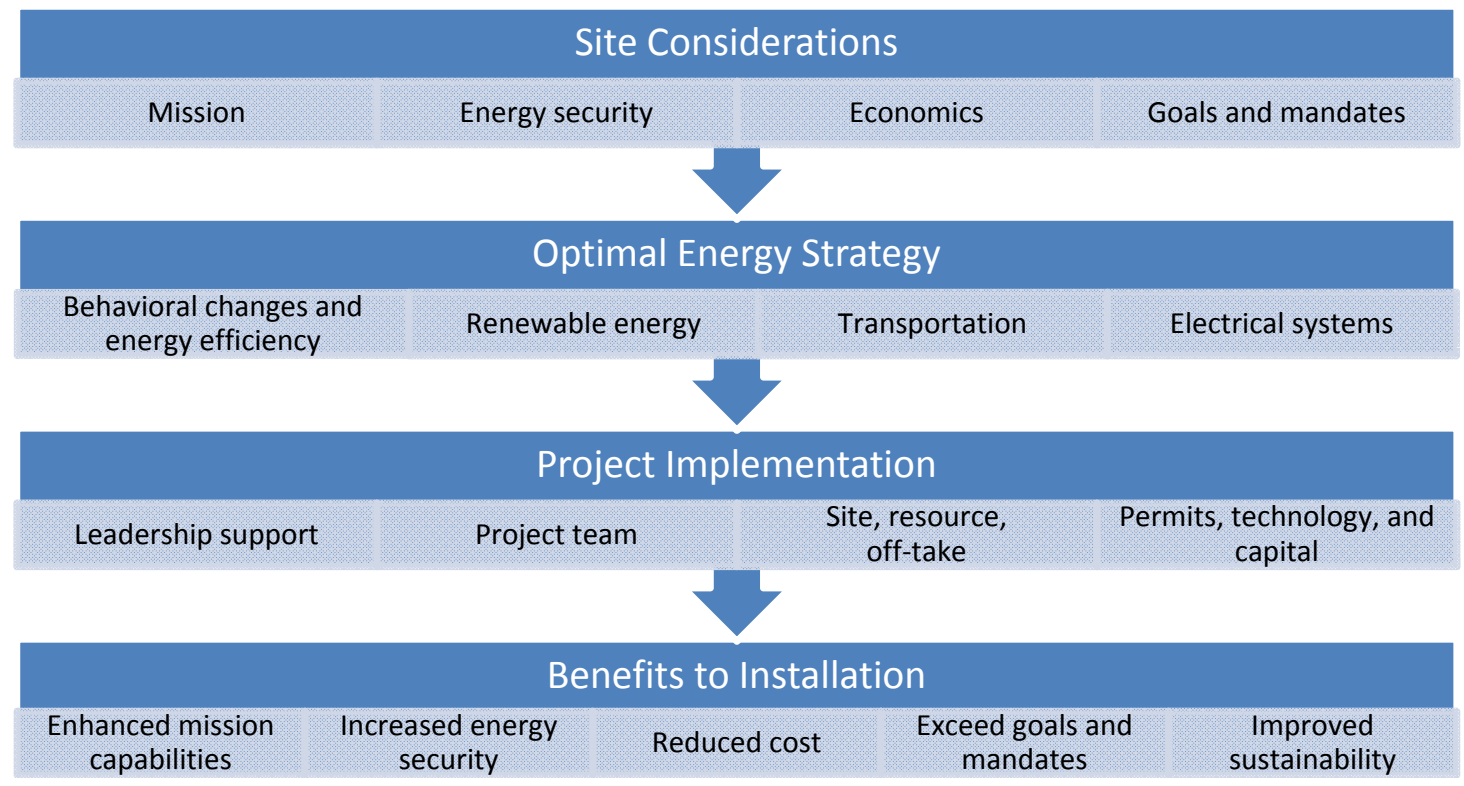

Figure 3: Flow diagram of net zero energy assessment and implementation

\section{Selected Resources}

\section{Definition of a Net Zero Energy Community}

Carlisle et al. (2009), NREL/TP-7A2-46065, Golden, CO, National Renewable Energy Laboratory, http://www.nrel.gov/docs/fy10osti/46065.pdf

Defines a net zero energy community and suggests a hierarchical approach to achieving net zero energy status

\section{Getting to Net Zero}

Crawley et al. (2009), NREL/JA-550-46382, Golden, CO, National Renewable Energy Laboratory, http://www.nrel.gov/docs/fy09osti/46382.pdf

Discusses the definition of net zero energy buildings and how they can be achieved

\section{Army Energy Goals}

http://army-energy.hqda.pentagon.mil/

Provides an overview of Army Energy Security Goals 


\section{Getting Started}

Conducting a net zero energy assessment is fundamentally an exercise in integrated energy project evaluation and planning. This section addresses first steps common to many organizational initiatives: making the case for the assessment and securing leadership support; establishing a team; and defining the project boundaries.

\subsection{Making the Case and Securing Leadership Support}

In order to demonstrate to decision makers and other stakeholders the value of the NZEI assessment, it's important for the installation energy manager or public works lead to establish a convincing case that relates potential outcomes to common motivators: improvements to mission performance, security of the energy supply and of the site, decreased or more predictable energy costs, and responsiveness to energy-related federal or DoD mandates. Key decision makers in the organization's chain of command should be identified, and how the assessment and its outcomes relate to their professional incentives understood.

The case for the assessment should reflect understanding of the installation's energy history, and especially recent and planned energy projects. It can help to become familiar with examples of other installations that have approached a comprehensive energy strategy, whether or not based on a net zero energy design point. Lessons learned, from successes as well as failures, can strengthen the case for an assessment. Knowledge of plans for major service changes or energy projects by local utilities can also add depth to the argument for the assessment.

Planned or potential major changes to the installation's mission or physical infrastructure, which might range from troop or mission reassignment to demolition of older structures to privatization initiatives, can have a major impact on the assessment and should also be explored.

The case for the assessment should be presented to key installation leadership, whose support is essential to eventually moving beyond a paper study to project implementation. Local leadership might consider the value of presenting higher up the chain of command. Additionally, the local leadership should develop compelling rationale and stories to advocate the net zero approach to all personnel on the installation. Ultimately, the people who work and live on the installation must embrace the net zero concept in order to create longstanding change.

\subsection{Establishing a Net Zero Energy Installation Team}

A net zero energy assessment will require a project lead as well as a dedicated team of individuals from a variety of areas for data gathering, analysis, and implementation. Personnel and departments represented on the NZEI assessment team should include:

- Installation management (such as the base commander)

- Energy manager

- Facilities and maintenance personnel

- Fleet vehicle manager

- Director of public works

- Contracting officer 
- Environmental manager

- Master planning

- Installation public affairs officer

- Installation security officer

- Utility company.

To augment the installation team, personnel from outside the installation can be brought in as needed to provide advice, expertise, and analytic support.

The team lead will coordinate efforts and champion the NZEI assessment concept on base. The team lead role will likely be held by a representative from the public works department such as the base energy manager. Not all of these people and departments will need to be involved in each step of the process; the team lead can engage them as needed.

This document is intended to be used by the team as a guide to explaining the NZEI assessment concept, conducting the assessment, and developing an optimal energy strategy for the installation.

\subsection{Defining the Project Boundaries}

One of the first actions of the team should be to agree on boundaries of the assessment, defining parameters including:

- Assessment goal: Potentially as straightforward as the identification of a set of energy projects to reach or approach a net zero energy installation, or to optimize a broader set of criteria.

- Geographic boundaries: The physical boundaries of the installation to be assessed, which may be a single base or a broader set of related areas.

- Energy use to be addressed: The form of energy to be addressed, which may include electricity, heat, and direct fuel use. In the general case, all energy use will be addressed in the baseline, but individual net zero energy assessments may focus on specific aspects of the installation's activities: buildings and facilities, public infrastructure, and transportation (nontactical, tactical). Tenants exist on many bases, and their energy use may be outside the purview of the base energy manager; support of their leadership, often extending to chains of command entirely separate from the main base management, will need to be secured.

- Special energy requirements: These may include specification of mission continuity requirements such as the ability to maintain a critical load for some period in conditions where the ambient utility grid is down (i.e., islanding).

- Timeline: While a well-planned assessment may be completed in under a year, the development and implementation of the resultant recommendations will likely take much longer due to the size and nature of the projects. The project timeline is influenced by factors such as permitting and contracting that are often lengthy processes. 
- Contingencies: Identify potential areas to expand work if goals are achieved faster than expected and identify actions that should follow to maintain the momentum of success. Similarly, identify difficult areas that may require increased resources or emphasis. 


\section{Determining the Baseline}

The first step in conducting a net zero energy assessment is to establish baselines for energy consumption and for related GHG emissions. The energy baseline is used to measure progress toward net zero energy installation status, while the GHG baseline provides a reference to determine the net effect on emissions of the proposed energy projects. Baseline data collection, key to a credible assessment, can present a significant challenge due to limitations in historically collected data and the number of people controlling it, who may have very different levels of buy-in to the assessment. In some cases where needed data doesn't exist, it may be necessary to collect data in parallel with other early assessment steps.

\subsection{Energy Baseline}

The goal is a summary of all types of energy used by the installation in its full range of mission and support activities; this includes electricity and natural gas provided by a utility or generated on-site, and all direct on-site fuel use. Data from the three most recent years is usually collected to anchor the baseline, and awareness of anticipated major changes in the installation's energy use (increases or decreases) is desired.

\section{Approach}

- Present baseline: Establishing the energy baseline is primarily an exercise in data collection. All entities using energy within the installation boundaries should be approached for energy use and cost data. Energy use data at the level of individual buildings or transport vehicle type is desired, but data may exist only at an aggregated level. The assessment team may determine the need to collect at least several months of data for certain energy uses if insufficient data exists. Energy cost data is often available on a monthly basis from utility bills.

- Future projection: Projections of future energy demand and cost for the continuation of present energy arrangements ("business as usual") are needed as a point of comparison to show the net effect of the projects proposed as a result of the assessment. Estimates of future energy costs may employ data from the Energy Information Administration or the Energy Escalation Rate Calculator (EERC) available from DOE. Estimates of future energy demand may be based on projected growth in installation population or square footage.

\section{Key Data and Information}

- Energy consumption: Data should be gathered regarding all forms of energy and fuel consumption in buildings, facilities, infrastructure, and vehicles within the installation boundary. At a minimum this should include electrical energy, thermal energy, and fleet fuel use. Other energy uses may also be included, such as tactical fuel use, commuter fuel use, and commercial air miles traveled. The more energy uses included, the more complete the picture of total installation energy consumption becomes. It is recommended to establish as complete a picture of installation energy use as possible even if some categories of use will not be further addressed in the assessment (e.g., tactical fuel use or commuter transport energy use).

- Cost: Current utility and fuel costs plus future cost estimates should be obtained or estimated for financial assessment. 
- Site-to-source ratio: The recommended energy accounting method based on source Btu requires determination or development of site-to-source ratios for energy unit conversion (see information and resources at the end of this section for assistance determining these factors).

- Goals and mandates: The federal, service, and site-specific goals - plus mandates for energy efficiency, renewable energy, and transportation - that the installation is required to meet in the near future must be accounted for in the NZEI assessment.

\section{Planning Considerations}

- What level of data is available (annual, monthly, daily, hourly)? Is the data representative?

- Is data available for all major energy users? What small energy users might be eliminated to simplify the assessment?

- How will the evolving mission of the installation impact energy consumption? Are there plans to demolish any buildings? Are any new equipment platforms being added?

- What energy data collection practices and/or devices should be implemented to create an energy database?

A diagram of the baselining process can be seen below.
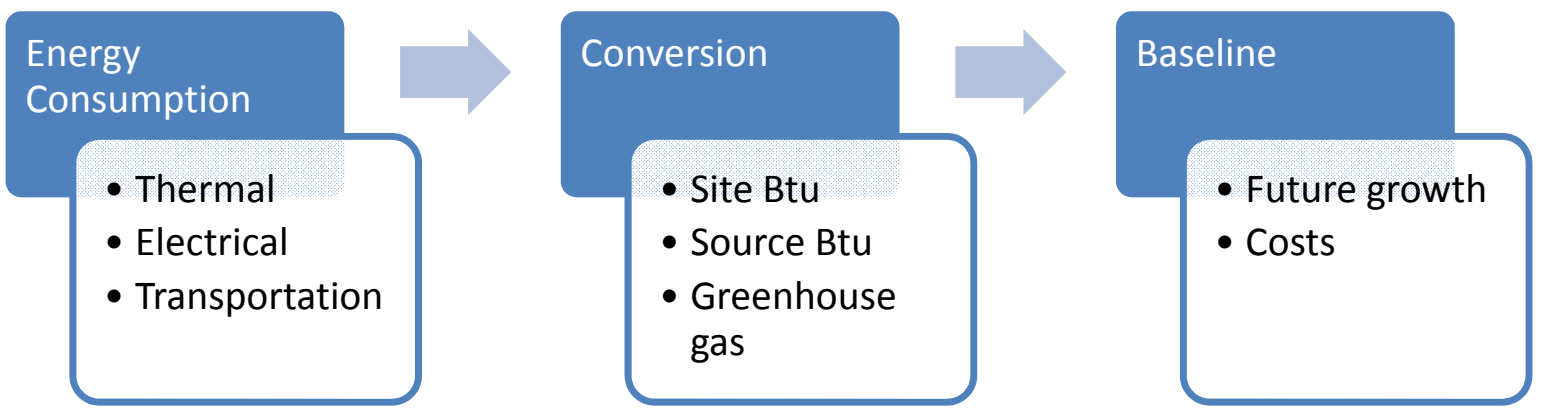

Figure 4: Flow diagram of the baseline process

\section{Selected Resources Energy Baseline}

\section{Source Energy and Emission Factors for Energy Use in Buildings}

M. Deru and P. Torcellini, National Renewable Energy Laboratory, 2007, http://www.nrel.gov/docs/fy07osti/38617.pdf

This report provides the energy and emission factors to calculate the source energy and emissions for electricity and fuels delivered to a facility.

\section{Energy Information Administration}

http://www.eia.doe.gov/

The U.S. Energy Information Administration (EIA) collects, analyzes, and disseminates independent and impartial energy information. 


\section{Energy Escalation Rate Calculator}

http://www1.eere.energy.gov/femp/information/download blcc.html\#eerc

The EERC computes an average annual escalation rate for fuel prices from the annual energy price forecasts of DOE's Energy Information Administration. This rate can be used to estimate energy escalation rates for financial analysis.

\subsection{Greenhouse Gas Baseline}

A basic GHG inventory is included as part of the net zero energy assessment. Executive Order (E.O.) 13514, signed on October 5, 2009, ${ }^{9}$ requires that federal agencies "measure, report, and reduce their GHG emissions from direct and indirect activities." To achieve these goals agencies must establish reduction targets for scope 1,2, and $3 \mathrm{GHG}$ emissions in absolute terms by fiscal year 2020 relative to a fiscal year 2008 baseline.

\section{Approach}

- Scope 1 (direct) emissions: First, an inventory is performed of on-site emissions from direct combustion. These typically include fuel used on-site for thermal applications such as natural gas or fuel oil, as well as transportation fuel like gasoline or diesel used in fleet vehicles. Activity data is usually collected in energy units (e.g., therms of natural gas) and then converted into equivalent tons of carbon dioxide by applying GHG-equivalent conversion factors.

- Note: To comply with the GHG requirements under E.O. 13514, nonenergy scope 1 emissions (e.g., methane emissions from on-site landfills and wastewater treatment facilities, and fugitive emissions from refrigerants and other electrical equipment) must also be included in agency inventories and reduction targets.

- Scope 2 (indirect) emissions: Scope 2 emissions primarily include off-site emissions generated by the serving utility company in the production of electricity used at the installation. The emissions are dependent on the type of fuel(s) used; a given utility may employ generation from coal, oil, natural gas, hydrodynamic, nuclear, wind, biomass, or solar sources. Data is usually collected in energy units (e.g., kWh of electricity reported on a utility bill) and then converted into equivalent tons of carbon dioxide by applying GHG-equivalent conversion factors.

A sample calculation would follow a method such as this; the Environmental Protection Agency's (EPA) E-grid ${ }^{10}$ provides an average emission factor of 1,883.08 lb. of carbon dioxide per megawatt hour for the Rocky Mountain Power Area-Western Electricity Coordinating Council (RMPA-WECC) region, ${ }^{11}$ and an installation in this region could use this factor to convert $\mathrm{kWh}$ to $\mathrm{GHG}$ equivalent.

\footnotetext{
${ }^{9}$ E.O. 13514, "Federal Leadership in Environmental, Energy, and Economic Performance.” October 8, 2009, http://www1.eere.energy.gov/femp/pdfs/eo13514.pdf.

${ }^{10}$ EPA E-grid, http://www.epa.gov/cleanenergy/energy-resources/egrid/index.html, Accessed May 2010.

${ }^{11}$ This region contains all of Colorado as well as part of New Mexico and Wyoming. A map of E-grid regions can be found at http://www.epa.gov/cleanenergy/documents/egridzips/eGRID2007V1_1_year05_SummaryTables.pdf. Accessed May 2010.
} 
FEMP is currently establishing guidelines for federal agencies to report GHG emissions. These guidelines are due to be released in the second half of 2010 and should be used by each installation to calculate its GHG baseline and subsequent inventories.

\section{Key Data and Information}

- Data for all on-site consumption of fuel - typically includes direct combustion of fuel for building thermal needs or industrial applications, and fuel use in fleet vehicles.

- Total energy purchased from the local utility, and the sources and averaged GHG emissions associated with that energy generation (e.g., E-Grid factors).

\section{Planning Considerations}

- Agency goals for GHG reduction.

- Agency goals based on an FY 2008 baseline.

- The inclusion of scope 3 emissions and fugitive emissions such as refrigerants.

Figure 5 represents the various scopes of GHG emissions.

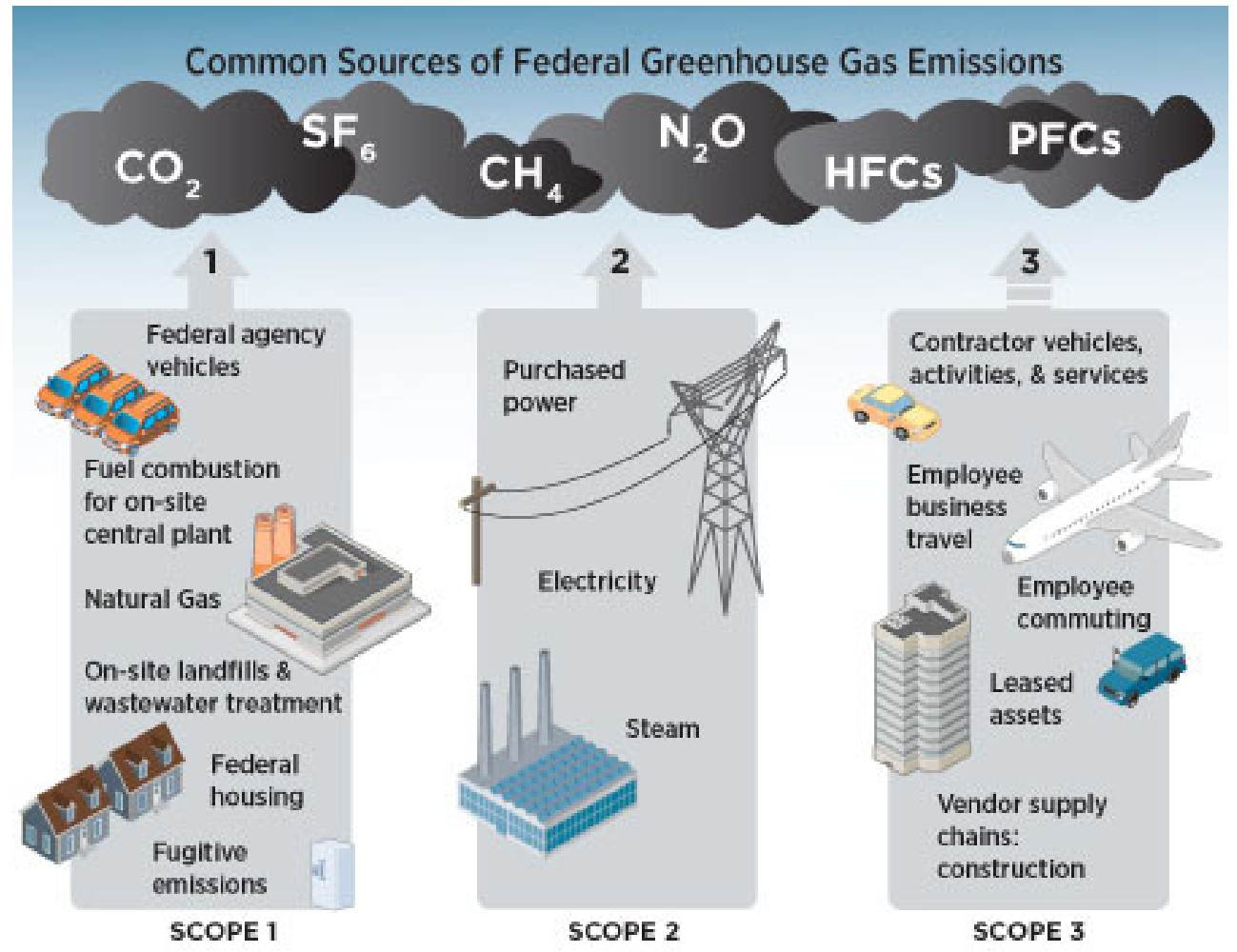

Figure 5: Common GHG emission sources and related scopes ${ }^{12}$

\footnotetext{
12 “Greenhouse Gas Basics,” FEMP, http://www1.eere.energy.gov/femp/program/greenhousegases basics.html. Accessed May 2010.
} 


\section{Selected Resources GHG Baseline Federal GHG Requirements}

http://wwwl.eere.energy.gov/femp/program/greenhousegases requirements.html

Reference on key greenhouse gas requirements that all federal agencies must meet under E.O. 13514

FEMP GHG Guidance and Protocols

http://www1.eere.energy.gov/femp/program/greenhousegases guidance.html

Guidance and tools necessary to ensure accurate and consistent GHG inventories across the federal government

\section{EPA GHG Equivalencies Calculator}

http://www.epa.gov/RDEE/energy-resources/calculator.html

An online calculator useful for converting energy data to GHG emissions and communicating these emissions in meaningful ways

\section{EPA Climate Leaders}

http://www.epa.gov/stateply/

Includes technical guidance on developing a GHG inventory and provides guidance on issues like inventory boundaries, emission sources, and reporting requirements - also provides a calculator tool for calculating an organization's emissions

\section{EPA E-Grid}

http://www.epa.gov/cleanenergy/energy-resources/egrid/index.html

Source of data on the air and GHG emissions associated with the generation of electric power in the United States 


\section{Reducing Energy Demand by Engaging People}

Once baseline energy use and GHG emissions are established, the next step in the net zero energy assessment is to identify the most economic ways to reduce the installation's energy demand. There are two main approaches: identifying actions to reduce energy use without the need for capital expenditures, and the implementation of energy-efficient technologies and design strategies. While the latter (addressed in the next section) is largely a technical exercise, the identification of opportunities for procedural, behavioral, process, or operational energysaving actions relies on engaging the attention and creativity of personnel, especially those with experience at the installation.

Security, economic, and environmental objectives support a DoD — and national - transition to clean energy that is usefully viewed as culture change, requiring individual awareness of energy, new habits of energy use, and continuing creative attention to ways of reducing energy demand. There is no silver bullet or purely technological solution to present energy challenges: even with energy-efficient technologies, the tendency is for energy demand to increase with growing populations and new generations of energy-consuming devices. So in conjunction with a NZEI assessment, DoD leaders should institutionalize some of the ways of engaging peoples' ingenuity to reduce energy demand. A recommended approach is outlined below.

\section{Approach}

- Assess potential demand reduction: Estimate energy demand reductions possible as a result of personnel actions, changes to processes, improvements to mission execution, and other sources (estimates in energy units and dollars). Create dedicated teams in functional areas across the installation's operations to identify actions to permanently minimize energy use. Candidate actions should have a neutral effect on mission performance, or improve it. The teams can solicit ideas from individuals across the installation.

- Consider energy use in facilities (lighting intensity, heating or air conditioning set points and hours of operation), transport (vehicle miles, need for travel versus teleconferencing/video-teleconferencing), and mission uses (required hours of use of aircraft/ships/subs/ground vehicles for training and operations).

- Implementation: Define a process to select and prioritize policies and actions, present to leadership for approval, and implement.

- Continuous improvement: Beyond the net zero energy assessment, peoples' ingenuity in saving energy can be engaged on a continuing basis.

○ Institute an energy awareness campaign.

○ Create competitions/contests/incentives for new ideas, or for the lowest energy use.

○ Encourage leadership/personnel teams to continue developing ways to save energy.

- Implement energy scoreboards to assess energy usage by individuals, buildings, or organizations and recognize best performers and practices. 


\section{Key Data and Information}

- Baseline data: Baseline energy use data (see previous section), and history of previous efforts to engage personnel in reducing energy demand.

- Tactical missions: Detailed understanding of training and operations, and associated regulations, tactics, techniques, and procedures.

- Base support mission: Knowledge of practices and regulations associated with environmental factors (e.g., temperature, required lighting levels), nutrition, sanitation, and morale/welfare/recreation.

\section{Planning Considerations}

- Institute attention to energy use as a normal part of all activities: planning, training, and mission execution.

- Make it a point of pride to help increase national energy independence through reducing dependence on energy from imported and/or "dirty" sources: self-sufficiency is a theme that naturally resonates with many military personnel. In deployed situations, energy savings can be tied to reducing convoy casualties.

- Consider energy's connection, beyond obvious electricity or fuel consumption, to water use, food, and other consumables.

- Leadership examples: Leading by example is a powerful influence across officer, enlisted, government civilian, and contractor elements of the military team.

FEMP has published several guides related to how to conduct an energy awareness campaign. The main steps identified by FEMP are shown in figure 6, along with a sample campaign poster focused on energy independence (figure 7).

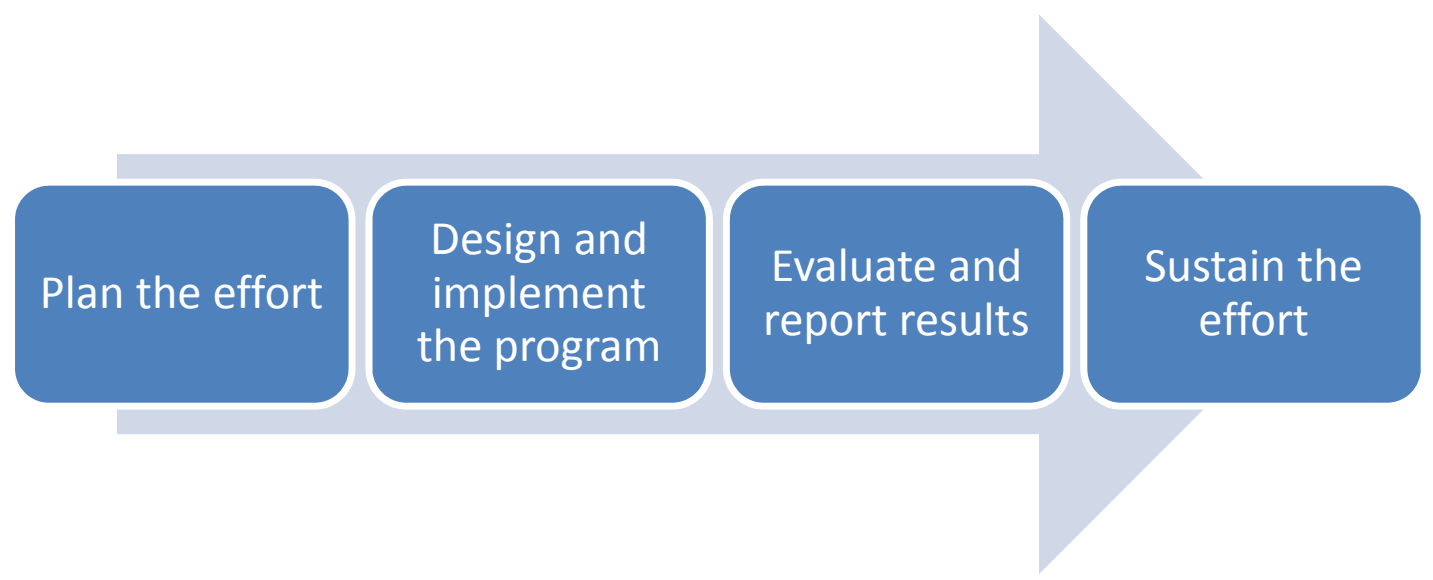

Figure 6: Main steps in an energy awareness campaign ${ }^{13}$

\footnotetext{
13 "Creating an Energy Awareness Program," FEMP, Page 3, http://www1.eere.energy.gov/femp/pdfs/yhtp_ceap_hndbk.pdf.
} 


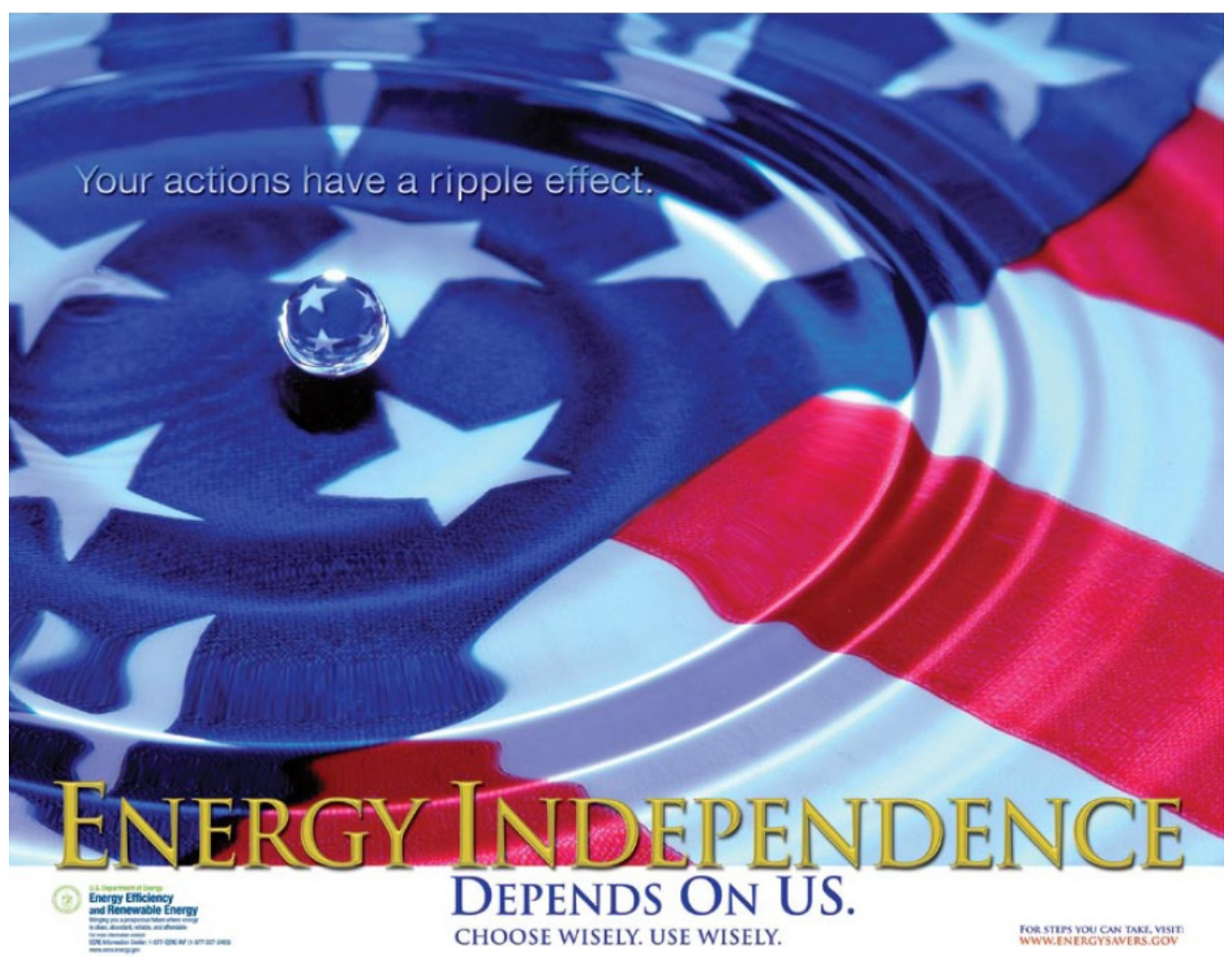

Figure 7: Sample energy awareness campaign material ${ }^{14}$

\section{Selected Resources}

\section{Creating an Energy Awareness Program}

http://www1.eere.energy.gov/femp/pdfs/yhtp ceap hndbk.pdf

Handbook from the Federal Energy Management Program on how to create an energy awareness program and campaign

\section{Promoting Behavior Based Energy Efficiency in Military Housing}

http://www1.eere.energy.gov/femp/pdfs/military hndbk.pdf

Handbook from the Federal Energy Management Program to promote energy efficiency in military housing

\section{Energy Managers Handbook}

http://www.wbdg.org/ccb/DOD/DOD4/dodemhb.pdf

Department of Defense Handbook for energy managers with tools to help facility and installation energy managers perform their jobs more effectively by answering questions and illustrating best practices

\footnotetext{
14 "Creating an Energy Awareness Program," FEMP, Page 8, http://www1.eere.energy.gov/femp/pdfs/yhtp_ceap_hndbk.pdf.
} 


\section{Energy Efficiency Assessment}

After determining energy consumption reduction through noncapital-intensive actions, an assessment of further demand reduction through energy efficiency technologies should be conducted throughout the installation's facilities and infrastructure. For the purposes of the NZEI assessment, potential energy efficiency projects can be scoped and the savings estimated by installation personnel and supported as needed by contractors. The outcome from this analysis should include a base-wide estimated savings potential. An investment-grade audit should be performed prior to project implementation by certified energy assessment professionals. The outcome from the investment-grade energy efficiency assessment should include estimated savings (in energy and cost), project cost, simple payback period, and annual operations and maintenance $(\mathrm{O} \& \mathrm{M})$ costs of energy efficiency measures. A quantitative estimate of energy reduction potential is needed to reduce the baseline energy consumption prior to the sizing of renewable energy or other generation technologies. An additional outcome should be benchmarking of the current relative energy efficiency of installation facilities.

\section{Recommended Approach}

- Energy efficiency screening and auditing: Trained installation personnel or a contractor should conduct detailed energy audits to determine energy efficiency improvement potential. The level of detail should provide enough information to successfully implement many projects with a high level of confidence. For example, for a lighting project, the detail would extend to measurement of lighting levels, counting the number of bulbs and ballasts in each room, and installation of instrumentation to measure the actual usage and operating hours of lighting. The energy efficiency screening and audit should be as comprehensive as possible and examine energy uses such as lighting, HVAC systems, building control systems, building envelope, water use, appliances, plug loads, industrial equipment, food service equipment, and installation infrastructure such as street lights.

- Energy benchmarking: Installation personnel should attempt to benchmark the relative energy efficiency of their buildings in comparison to other similar facilities. Benchmarking allows for the determination of relative energy efficiency potential and highlights the large energy users on an installation. A basis for comparing the installation to other facilities is an energy use index (EUI) that calculates a ratio of kBtu used per square foot. The installation EUI can be compared to that of other facilities by age, location, type, or other factors. Energy efficiency goals could be set based on achievement of a new EUI (federal mandates for energy efficiency are set in this manner). For example, one could set a goal that all installation office buildings will achieve the average EUI of an ENERGY STAR ${ }^{\circledR}$ qualified commercial building.

\section{Other Potential Approaches}

- Building energy modeling: Build computer models of selected installation facilities to determine savings from candidate energy efficiency or conservation measures.

- Engage the private sector or utility in a performance contract: Explore a performance contract such as an energy savings performance contract (ESPC) or utility energy 
services contract (UESC) where the private sector or utility helps determine potential savings and energy conservation measures.

- Basic building walk-throughs: If resources are not available to pursue a more detailed audit or screening, a more basic assessment can provide sufficient information to proceed with the NZEI assessment. This screening consists of building walk-throughs where potential energy-saving projects are identified, leading to rough estimates of energy efficiency potential. This level of assessment will not be sufficient for project implementation. Before any projects are implemented, an investment-grade audit should be conducted to inform project proposals. A basic energy screening may identify measures for energy savings such as replacing incandescent light bulbs with compact fluorescent light bulbs, replacing old or inefficient boilers, or identifying the need for building retro-commissioning.

\section{Key Data and Information}

- Existing facilities: Obtain data and information on existing facilities and their energy consumption. Sample data is listed below.

○ Installation location details such as latitude and longitude.

○ Building details such as:

- Area (square feet)

- Building-specific energy consumption (e.g., $\mathrm{kWh} /$ square foot)

- Building type (office, warehouse, etc.)

- Building usage (average hours per day)

- Building age (year built).

○ Three years of energy bills for fuel, thermal (natural gas, fuel oil, etc.), and electrical energy.

- If possible, total water usage data should also be collected.

- If possible, an estimate of the end use of thermal and electrical energy should be collected.

○ Locations of meters, gauges, and other energy measurement devices.

○ Load profiles from building energy bills or advanced meters.

○ Building drawings.

○ Age, type, and efficiency of the lighting, heating, cooling, and ventilating equipment used in each building.

○ Information regarding previous energy projects undertaken.

\section{- New construction plans:}

○ Location.

○ Building details such as type and usage. 
○ Design specifications and estimated energy consumption (i.e., 10\% below code and average EUI).

\section{Planning Considerations}

- The level of funding and data available for a NZEI assessment could determine the level of detail possible for efficiency assessment.

- Federal mandates require an energy efficiency reduction of 30\% relative to a 2003 baseline by 2015 .

- Federal mandates require comprehensive energy and water evaluations of $25 \%$ of covered facilities each year.

- A $30 \%$ reduction in facility energy use is a good rule of thumb to estimate energy efficiency potential.

- All buildings are included in the NZEI assessment - this includes goal exempt buildings, ${ }^{15}$ which are typically not reported in DoD energy consumption data and are not subject to federal mandates.

- Implementation of an energy management system should be considered if the installation doesn't already have one.

- Given the high cost of some renewable energy generation technologies, a site interested in becoming a net zero energy installation should examine energy efficiency measures that might not typically be considered in an energy assessment but could be more costeffective options than some energy generation technologies. For example, building envelope upgrades that would not normally be implemented should be considered since they might be more cost-effective than PV systems.

- The opportunity for switching between energy types or sources should be considered in the context of energy efficiency upgrades. For example, if a base were to utilize heat pumps that were powered with renewable electricity rather than natural gas heating systems, the installation could increase its chances of becoming net zero. However, when analyzing this type of project, consideration of other priorities such as cost must be maintained.

Figure 8 shows how conservation and energy efficiency should reduce the established baseline, resulting in a new baseline where renewables should be utilized to meet the remaining load.

\footnotetext{
${ }^{15}$ Federal buildings are subject to mandated energy efficiency reductions under the National Energy Conservation Policy Act (NECPA) and E.O. 13423. Some buildings are exempt from these requirements. Guidelines for exempting buildings can be found at http://www1.eere.energy.gov/femp/pdfs/exclusion_criteria.pdf.
} 

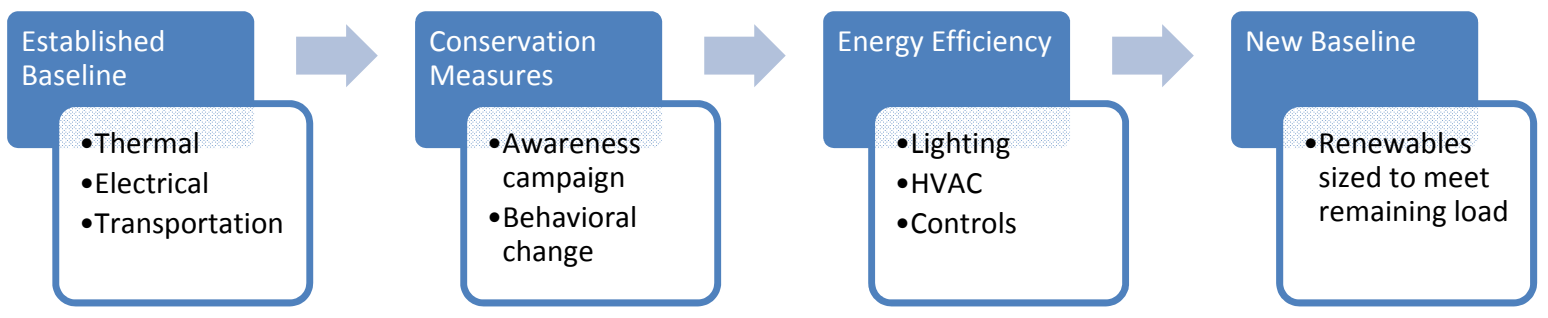

Figure 8: Baseline reduction process

\section{Selected Resources}

Benchmarking

\section{EPA ENERGY STAR Building Database}

http://www.energystar.gov/index.cfm?fuseaction=labeled buildings.locator

Provides a listing of ENERGY STAR buildings by geographic location-can be used to compare the EUI of these buildings to an installation

\section{EPA Target Finder}

http://www.energystar.gov/index.cfm? $=$ new bldg_design.bus target_finder A tool that enables architects and building owners to set energy targets for a building and receive a score relative to other buildings

\section{Commercial Building Energy Consumption Survey}

http://www.eia.doe.gov/emeu/cbecs/contents.html

Provides an overview of commercial building energy consumption

\section{Residential Energy Consumption Survey}

http://www.eia.doe.gov/emeu/recs/recs2005/c\&e/summary/pdf/tableus1part1.pdf

Provides an overview of residential energy consumption

\section{Labs 21 Benchmarking Tool}

http://labs21.1bl.gov/CompareData.php

Examines laboratory energy consumption and allows users to benchmark their laboratory

facility against others

\section{Calculation Tools}

\section{Building Energy Modeling Software}

DOE 2: http://www.doe2.com/ eQUEST: http://www.doe2.com/eQuest/

Advanced building energy modeling software - requires a significant amount of knowledge and information to use but can model energy savings opportunities

\section{EPA Portfolio Manager}

http://www.energystar.gov/index.cfm?c=evaluate_performance.bus_portfoliomanager 
Energy management tool that allows users to track and assess energy and water consumption across an entire portfolio of buildings

\section{Lists of Energy Savings Calculators}

http://www1.eere.energy.gov/femp/technologies/eep eccalculators.html

http://www1.eere.energy.gov/calculators/homes.html

Several energy savings calculators that allow users to estimate energy and cost savings from various energy efficiency measures

\section{Home Energy Saver}

http://hes.lbl.gov/

Energy savings calculator for homes

\section{Summary Information}

\section{Federal Mandate Information}

http://www1.eere.energy.gov/femp/regulations/requirements by reg.html Information on federal energy laws and regulations

FY08 Energy Management Data Report, U.S. Department of Defense http://www.acq.osd.mil/ie/energy/library/DoDenergymgmtrpt08.pdf

Overview of DoD energy consumption in fiscal year 2008

\section{Assessment of Technical Potential for Achieving Net Zero-Energy Buildings in the Commercial Sector}

Griffith, Long, Torcellini, and Judkoff; National Renewable Energy Laboratory; December 2007; NREL/TP-550-41957, http://www.nrel.gov/docs/fy08osti/41957.pdf.

2007 NREL report that addresses the net zero energy potential of standard new commercial building by climate zone

\section{DoD Ground Source Heat Pump Assessment}

http://www.acq.osd.mil/ie/energy/library/GSHP-Report JAN242007.pdf

Report on the potential use of ground source heat pumps at DoD facilities 


\section{Renewable Energy and Load Reduction Assessment}

For a net zero energy installation, the balance of energy consumption - after conservation and energy efficiency improvements are accounted for-is met with renewable energy. Screening tools are used to identify candidate renewable energy projects. The optimal mix of renewable energy technologies for each installation is strongly site-specific, and may be identified using an optimization approach. Other nonrenewable load reduction projects (examples include cogeneration systems and fuel cells) should also be considered; when project recommendations may be developed, local planning criteria may prioritize these over some renewable projects.

\subsection{Energy Project Screening}

The first step in a renewable energy assessment is the use of screening tools to examine the renewable energy potential on an installation's property. These tools should serve as a filter for the elimination of less compelling projects from further assessment. The result of this screening is the identification of selected technologies for additional assessment.

\section{Approach}

- Renewable energy resource mapping: Obtain resource maps for the location to determine the potential feasibility of projects.

- For example, high average (measured) wind speeds indicate significant wind project potential, and nearby landfills indicate waste-to-energy project potential.

- Possible renewable energy technologies include solar photovoltaics (PV), concentrating solar power, wind, solar hot water, combined heat and power, biomass (using various fuel sources), daylighting, solar ventilation preheating, geothermal, ocean thermal, hydrodynamic systems, and waste-to-energy. Each technology has its own set of data needed to establish viability at a given site.

- Screening software: Utilize software to conduct a high level renewable energy assessment to determine feasibility of projects. Several software screening tools are identified in the Selected Resources subhead in this section.

- Survey of other local projects: Other nearby energy projects should be reviewed to determine promising technologies. These projects will likely have already evaluated the same resource and economic incentives as the installation under assessment.

- Local requirements: Discuss the results of the assessment with installation personnel and technology experts to incorporate site-specific criteria into the assessment.

○ As an example, installations with flying missions are often not interested in wind turbines due to radar interference concerns (an issue that is being studied at present).

\section{Key Data and Information}

- Renewable resources: Local resources related to the technologies being considered, obtained from catalogued data or on-site measurements. Where sufficient data is not available, it may be necessary to collect data for periods of up to one year to capture seasonal variation. 
- Facilities and infrastructure: Facilities and infrastructure on the installation available for energy projects:

○ For example, what carports and building rooftops might be available for PV?

- Grid characteristics, addressed in a subsequent chapter, must be understood to ensure that new renewable generation can be transmitted and distributed. Improvement may be required.

- Energy plans: Current plans and past studies for renewable energy projects.

- Site availability: Availability of land for large-scale projects such as concentrating solar power (CSP) or wind turbines.

- Availability of funding for renewable energy projects: Availability of funding for projects from programs such as the Environmental Security Technology Certification Program, which provides grants for renewable energy demonstration projects on military installations.

\section{Planning Considerations}

- Consider the willingness of the installation to take a technology risk on pre-commercial or demonstration technologies.

- It is important to consider all potential technologies, such as fuel cells, microturbines, and solar pool heaters, and not just more common renewables such as PV and wind.

\subsection{Detailed Technical Assessment}

After the screening has been done and it has been determined which technologies appear viable for the installation, further in-depth assessment of those technologies is needed to ensure they not only work technically, but can satisfy installation goals and constraints. Sample factors to consider would be project capital costs, project energy savings, regional military energy plans, environmental benefits, possible mission impacts, and energy security. The output is a set of recommendations for renewable energy projects.

\section{Approach}

- Ensure that specific proposed siting meets the requirements of the individual technology (e.g., slope of land for solar PV projects).

- Utilize detailed modeling software such as Solar Advisory Model (SAM) or Hybrid Optimization Model for Electric Renewables (HOMER) to examine project size and economics.

- Consult with internal or external technology experts regarding project potential at a specific site.

- Issue a request for information (RFI) or request for proposal (RFP) to the private sector for specific projects.

- Develop a weighted decision matrix for the site to incorporate goals, concerns, mandates, and other information into technology decisions. 


\section{Key Data and Information}

- Siting information (present and past land use, likely environmental concerns, ownership).

- Information on federal, state, and local economic incentives.

\section{Planning Consideration}

- Many renewable energy technologies, such as PV and wind, result in intermittent power generation. Intermittent generation is more difficult to incorporate into a microgrid than dispatchable generation such as biomass power.

The military is already a leader in deploying renewable energy technologies. Several renewable energy systems already installed on military installations are shown in the figures below.

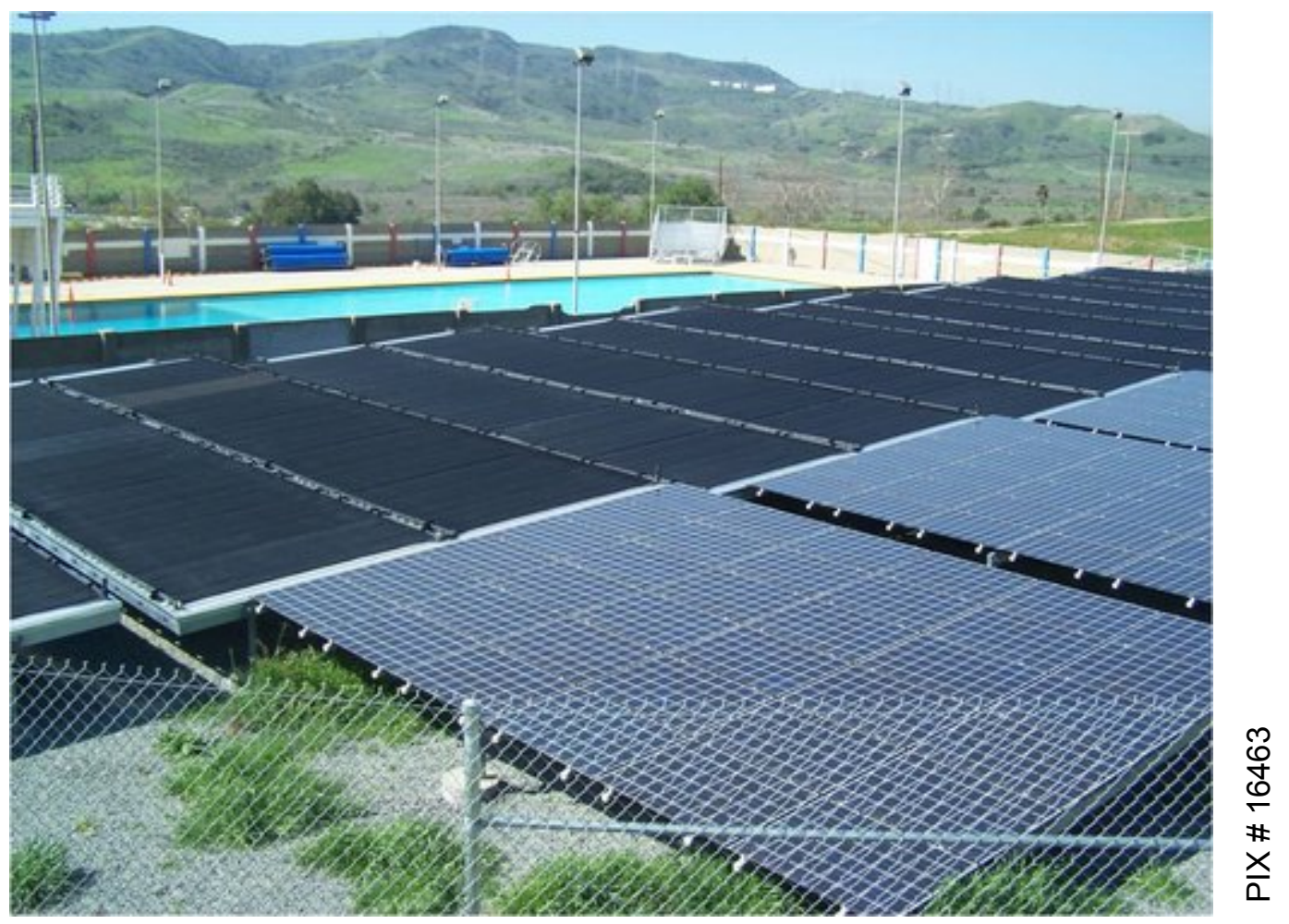

Figure 9: Solar pool heating system and solar photovoltaic system at Camp Pendleton, CA 


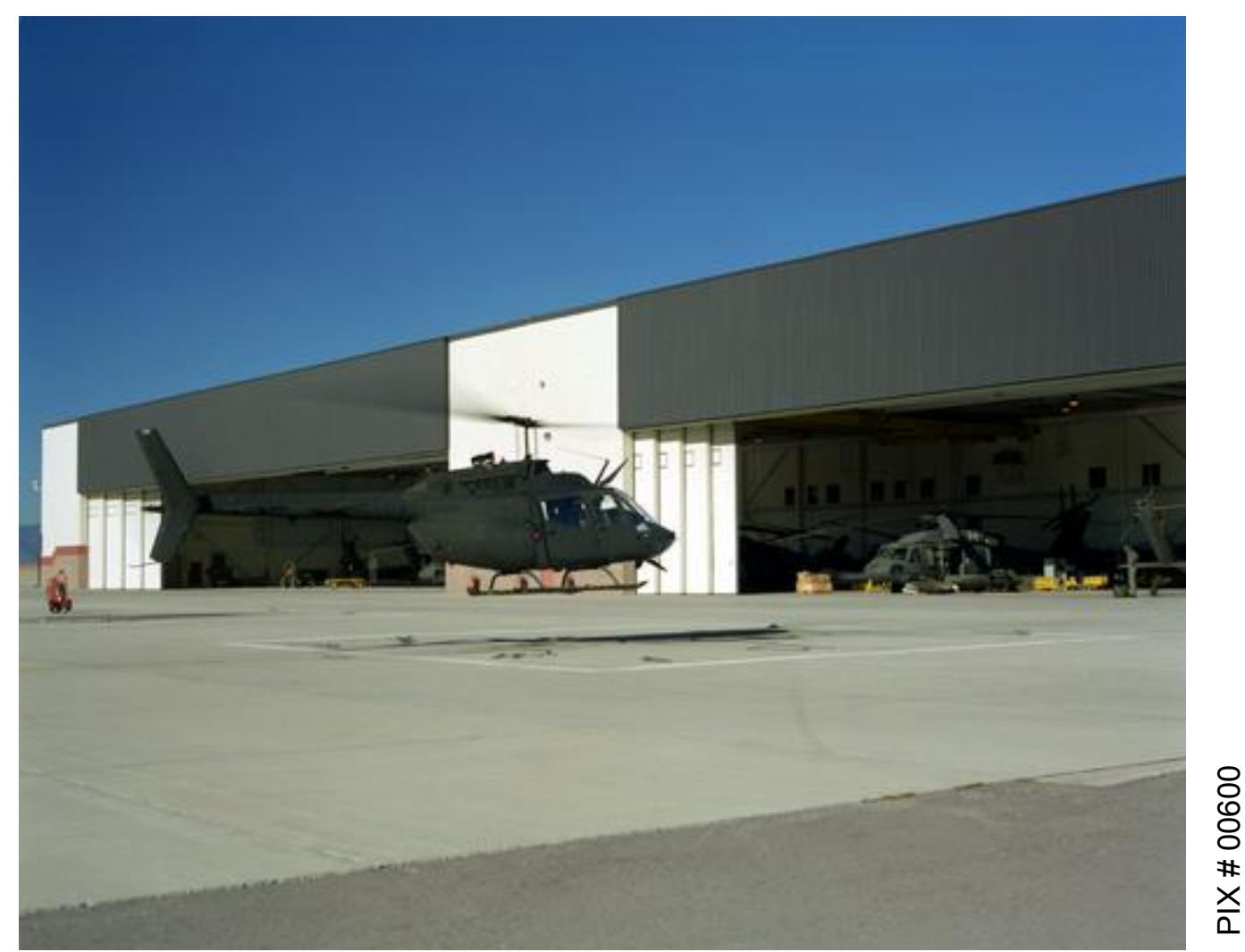

Figure 10: Solar ventilation preheating at Fort Carson, CO

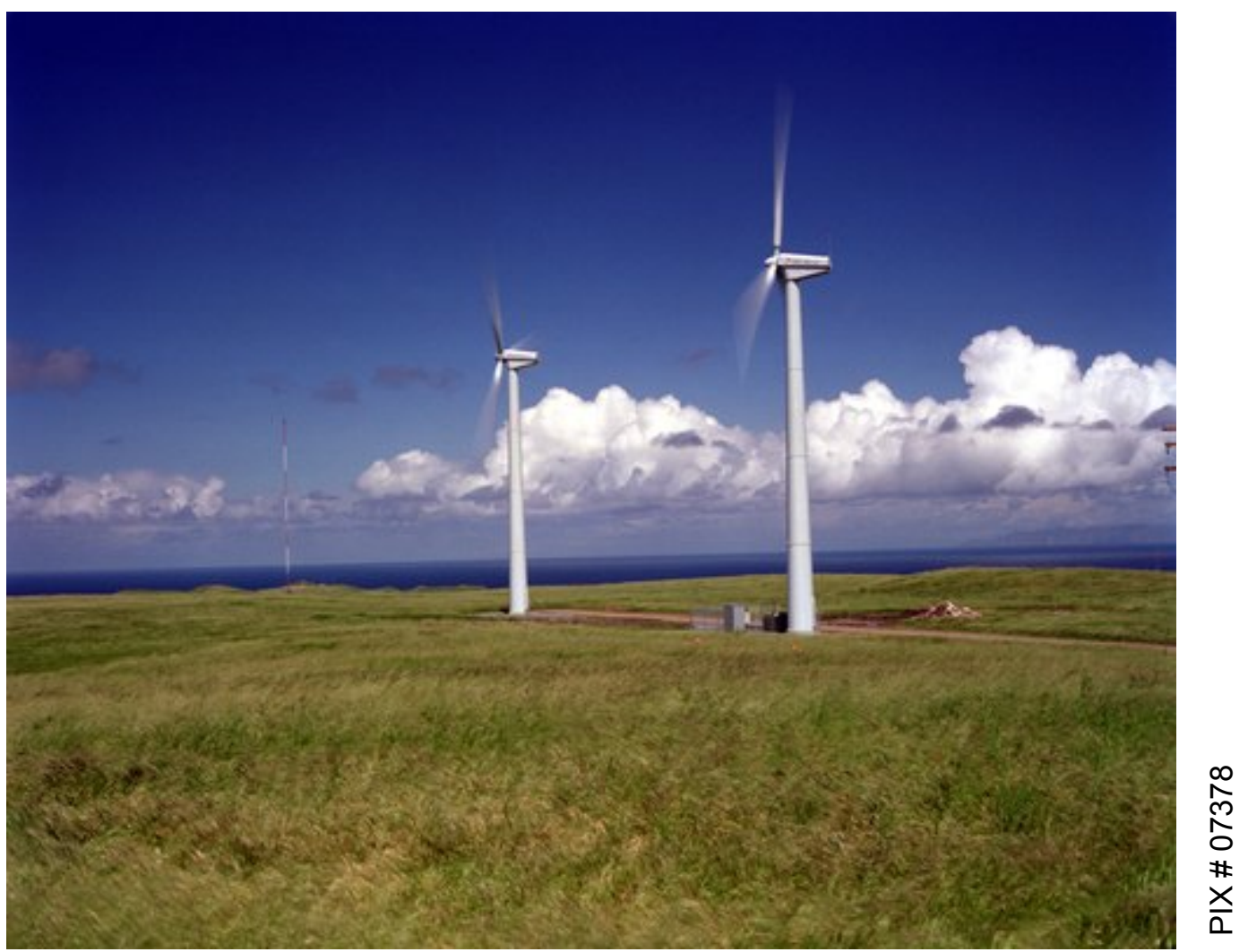

Figure 11: Wind turbines at a U.S. Navy installation, San Clemente Island, CA 


\section{Selected Resources}

Renewable Energy Overview

http://www1.eere.energy.gov/femp/technologies/renewable_energy.html

FEMP Renewable Energy Information Portal-provides a variety of information on

requirements, technologies, resources, purchasing renewable power, and training

\section{Solar Resource Maps and Tools}

http://www.nrel.gov/gis/solar.html

Resource maps that can be utilized to determine solar project potential

\section{Solar Power Prospector (Primarily for CSP)}

http://mercator.nrel.gov/csp/

Tool that can be utilized to determine CSP project potential at a specific location

\section{In My Backyard (IMBY)}

http://www.nrel.gov/eis/imby/

A solar mapping tool designed to calculate energy potential for a PV array covering a given area at a selected site

\section{Solar Water Heating and Solar Vent Pre Heat Maps}

http://www.nrel.gov/gis/femp.html\#water

Resource and payback maps for solar hot water and solar vent preheat across the United States

\section{Wind Resource Maps}

http://www.windpoweringamerica.gov/wind maps.asp

Resource maps that can be utilized to determine wind project potential

\section{Bio Power Mapping Application}

http://rpm.nrel.gov/biopower/biopower/launch

Resource maps, plant locations, and other information that can be utilized to determine biomass project potential

\section{Federal Mandate Information}

http://www1.eere.energy.gov/femp/regulations/requirements by subject.html\#re

Information on federal energy laws and regulations

\section{HOMER}

http://www.homerenergy.com/

A tool for analyzing electric hybrid power systems, which contain a mix of renewable energy, conventional generators, and batteries

\section{Solar Advisory Model Tool}

https://www.nrel.gov/analysis/sam/

A tool that allows for a simple or detailed production analysis and financial modeling of PV and CSP solar energy systems 
PV Watts Solar Analysis Tool

http://www.nrel.gov/rredc/pvwatts/

A tool that allows for a simple analysis of potential PV production and cost savings

\section{RET Screen Analysis Tool}

http://www.retscreen.net/ang/home.php

A software tool that allows for the analysis of numerous renewable energy and energy efficiency technologies

\section{Solar Pool Information and Calculator}

http://energy.sandia.gov/index.htm

Information regarding implementation of solar hot water pool heating systems as well as a calculator to estimate savings

\section{Hydropower and Ocean Energy Resources and Technologies}

http://www1.eere.energy.gov/femp/technologies/renewable hydropower.html

Information regarding hydropower and ocean energy technologies

\section{Geothermal Technology Information}

http://www1.eere.energy.gov/geothermal/

Information about geothermal energy such as technology, resources, and project financing

\section{Combined Heat and Power}

http://www1.eere.energy.gov/femp/technologies/derchp.html

Information on combined heat and power technologies such as technology overview, market studies, federal requirements, and other resources

\section{Waste-to-Energy}

http://www.epa.gov/rdee/energy-and-you/affect/municipal-sw.html

Basic information regarding producing energy from municipal solid waste 


\section{Transportation Assessment}

An assessment of the possibility to reduce fleet vehicle fuel consumption and switch to alternative fuels is an important part of the NZEI assessment. The output is an estimate of fleet savings potential based on recommendations such as vehicle replacement, fleet size reduction, or alternative fuel use.

\section{Approach}

- Determine if the current number of vehicles in the fleet could be reduced. The basis for this determination is typically vehicle usage, and a common metric is annual miles travelled. Often if vehicles are sorted by annual miles travelled, there appears to be an almost natural division between annual low mileage vehicles and higher mileage vehicles. A recent NZEI assessment revealed that greater than 55\% of a base's vehicles were travelling less than 5,000 miles per year. Low mileage vehicles are possible candidates for reduction. If one or two vehicles assigned to a particular organization are often under-utilized, but eliminating them entirely leaves the organization without vehicle access, a "pooling" concept often makes sense. For example, if eight separate organizations had a total of 10 vehicles that were generally under-utilized, replacing these 10 vehicles assigned to eight separate organizations with 6 vehicles that could be accessed by all eight organizations might be a solution.

- Examine if certain fleet vehicles could be downsized and replaced with more efficient models. Some possible replacement opportunities or strategies include: replacing a fourwheel-drive pickup or SUV with a more efficient two-wheel-drive vehicle; replace a pickup/SUV with a sedan or van; consider a neighborhood electric vehicle (NEV) in lieu of a sedan, consider a four-cylinder vehicle instead of a six-cylinder vehicle, a sixcylinder vehicle instead of an eight-cylinder vehicle, a light duty pickup instead of a medium duty pickup, a subcompact sedan instead of a compact sedan, a compact sedan instead of a mid-sized sedan, etc.; and consider acquiring hybrid electric vehicles (HEVs) especially if alternative fuel and/or alternative fuel vehicles (AFVs) are not available.

- Explore opportunities to reduce petroleum consumption via alternative fuel use. Utilize the Alternative Fueling Station Locator - the Web address is provided at the end of this chapter - to determine if alternative fuels are available nearby. Acquiring an AFV that does not have access to alternative fuel does very little to displace petroleum, increases the number of waivers required under EPAct 2005, and should generally be avoided as AFVs are often more expensive than gasoline-fueled vehicles. Assuming AFVs and alternative fuel are available, one must choose what AFV and alternative fuel to use. The most common alternative fuel used by federal fleets today is E85-a mixture of 85\% ethanol and $15 \%$ gasoline. Even though gasoline comprises $15 \%$ of E85, the entire gallon of E85 is considered alternative fuel for federal fleet reporting purposes. AFVs that use E85 are typically flex fuel vehicles (FFVs), meaning they are capable of using gasoline or E85. Compressed natural gas (CNG) fueled vehicles are available, and CNG offers an added benefit of significant GHG reductions when used as an alternative fuel. Less commonly used alternative fuels are liquefied natural gas (LNG), liquefied petroleum gas (LPG or propane), hydrogen, and electricity. Biodiesel is a fuel commonly used in blends of $20 \%$ biodiesel fuel mixed with $80 \%$ diesel fuel-hence its designation as B20. 
Biodiesel fuel can be used in diesel engines, although fleets should avoid the practice of alternating B20 and conventional diesel fuel in diesel engines.

- Assess the fuel distribution infrastructure at and near the installation to determine efficiency improvement potential and the possibility to install on-site alternative fuel infrastructure. Constructing new infrastructure can be time-consuming and expensive-a fast-fill CNG station can cost several hundred thousand dollars, for example. Ideally, alternative fuel infrastructure already exists on-site, but if not, there are several options to consider. E85 and biodiesel fuel can be stored in conventional gasoline and diesel storage tanks with minor, relatively inexpensive modifications. Electric charging infrastructure is generally not cost prohibitive either. However, infrastructure is often not necessary as alternative fuel is commercially available just outside many military installations.

\section{Key Data and Information}

- Availability of alternative fuels at or near the installation. The Alternative Fueling Station Locator (link provided under the Selected Resources subhead) can help with this task.

- Surveys can be a valuable tool to ask fleet personnel (drivers, maintenance personnel, fuels experts, etc.) for their opinions on how to reduce petroleum consumption and how to be more efficient in vehicle operations.

- Inventory of the installation's fleet vehicles, including type, miles traveled, age, typical use, and other factors. Inventory data could be collected in a variety of formats. A sample spreadsheet is shown in figure 12 .

\begin{tabular}{|c|c|c|c|c|}
\hline Vehicle & Sedan & Pickup & Van & SUV \\
\hline Manufacturer & Chevy & Ford & Dodge & Ford \\
\hline Model & Impala & F150 & Caravan & Explorer \\
\hline Year & 2007 & 2003 & 2005 & 2008 \\
\hline Fuel & E85 & CNG & E85 & Gas \\
\hline $\mathbf{G V W}^{1}$ & 4,554 & 7,700 & 5,400 & 5,880 \\
\hline Miles & 19,413 & 41,171 & 12,226 & 9,880 \\
\hline Location $^{2}$ & 80132 & 20005 & 20407 & 23240 \\
\hline Use $^{3}$ & $P$ & C & C & LE/ER \\
\hline Dedicated $^{4}$ & $\mathrm{~N}$ & $\mathrm{~N}$ & $\mathrm{~N}$ & $\mathrm{~N}$ \\
\hline Drive $^{5}$ & & 2 & & 4 \\
\hline GSA Lease $^{6}$ & Y & Y & $\mathrm{N}$ & Y \\
\hline Fuel Use $^{7}$ & 226 & 314 & 412 & 519 \\
\hline
\end{tabular}

\section{Figure 12: Sample fleet inventory data collection template}

1 Gross vehicle weight — certain federal mandates apply only to light duty vehicles (less than 8,500 lb.); also used to determine acceptable replacements

2 Location - typically a ZIP code; or preferably, via latitude/longitude coordinates

3 Use - refers to vehicle use, and vehicles can be categorized in several categories. Three common categories are: passenger $(\mathrm{P})$, cargo $(\mathrm{C})$, or law enforcement/emergency response (LE/ER).

4 A dedicated vehicle ( $\mathrm{Y}$ for yes, $\mathrm{N}$ for no) can only run on alternative fuel.

5 Drive (2 for two-wheel drive, 4 for four-wheel drive) - typically refers to pickups and SUVs

6 GSA lease (Y for yes, N for no) - a vehicle leased from the General Services Administration

7 Annual or year-to-date fuel use in gallons or equivalents, preferably by fuel type, since some vehicles are capable of using E85 or gasoline 


\section{Planning Considerations}

- Can electric vehicles be integrated into the overall energy solution (e.g., powered by onsite renewables, and possibly serve as backup energy storage for the installation)?

- Fleet vehicles are under the control of the installation fleet manager and are subject to federal mandates.

- Tactical fuel use at a base or installation has the potential to dwarf the fuel use of commuters and vehicle fleets, especially if the base has a large number of aircraft and/or armored vehicles. For example, one recent NZEI assessment revealed that more than $90 \%$ of total fuel use on base was used for tactical purposes.

- Fuel used for commuting and for other travel (e.g., commercial air travel for business) is not directly addressed as part of a NZEI assessment. This fuel use could be addressed external to NZEI assessment efforts, and will likely attain more visibility as GHG accounting and reduction efforts gain momentum in the future.

- A fleet manager should incorporate fuel efficiency into their vehicle acquisition strategy. Additionally, fleet managers should optimize their spending approach to not only include vehicle acquisitions but also projects like funding the development of alternative fuel infrastructure.

The U.S. government's federal fleet is one of the largest in the world with more than 600,000 vehicles, and it already has numerous AFVs in service. ${ }^{16} \mathrm{~A}$ breakdown of these AFVs is shown in figure 13 .

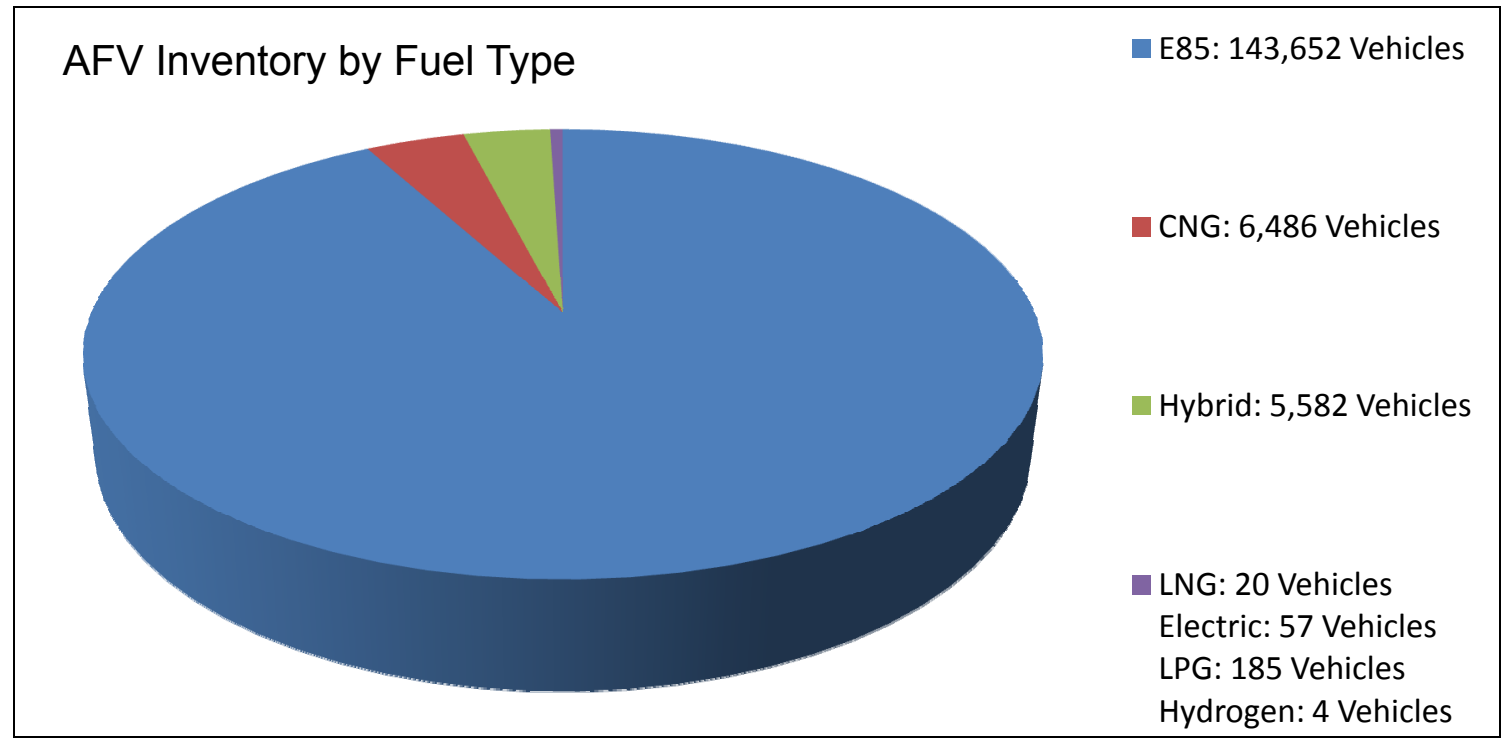

Figure 13: Total AFV inventory of federal agencies ${ }^{17}$

\footnotetext{
16 "Federal Fleet Program Overview," FEMP, http://www1.eere.energy.gov/femp/pdfs/fedfleet overview.pdf. Accessed May 2010.

${ }^{17}$ Vehicle inventory data pulled from "Federal Fleet Report, Fiscal Year 2009," General Services Administration, page 75, https://fastweb.inel.gov/FFR2009.pdf.
} 
However, the acquisition of alternative fuel fleet vehicles by federal agencies does not always follow an optimal strategy. Figure 14 below is an illustration of one federal agency's AFV acquisition strategy from a few years ago. The first row is what the agency actually achievedacquiring 2,161 AFVs at a cost of $\$ 1.2$ million, of which less than $11 \%$ of acquired AFVs had access to alternative fuel. Compare this strategy with results using an optimization tool. The "Max EPAct" strategy could only acquire 21 more AFVs than what the agency actually accomplished, so from an AFV acquisition standpoint, the agency did well. But for less than $25 \%$ of the agency's budget $(\$ 281,000)$, the agency could have acquired the requisite $75 \% \mathrm{AFVs}$ under the "Min Cost" strategy. The "Max AF Use" shown in the bottom row of the table is considered perhaps the ideal strategy: for $\$ 822,000$, EPAct acquisition requirements could have been met, nine alternative fuel stations retrofitted and/or built, and more than $40 \%$ of acquired AFVs would actually have access to alternative fuel. The remaining $\$ 400,000$ could have been used for more infrastructure development, or immediate fleet needs. These optimization tools should be utilized as part of a transportation assessment and AFV acquisition strategy, if possible.

\begin{tabular}{|c|c|c|c|c|c|}
\hline Strategy & Cost & AFVs Acquired & EPAct \% & $\begin{array}{c}\text { \# Alternative Fuel (AF) } \\
\text { Stations Constructed }\end{array}$ & $\begin{array}{c}\% \text { Acquired AFVs } \\
\text { with Access to AF }\end{array}$ \\
\hline Actual Results & $\$ 1.2 \mathrm{M}$ & 2,161 & $>100 \%$ & 0 & $10.6 \%$ \\
\hline "Max EPAct" & $\$ 1.2 \mathrm{M}$ & 2,182 & $134 \%$ & 0 & $13.1 \%$ \\
\hline “Min Cost" & $\$ 281 \mathrm{~K}$ & 1,239 & $75 \%$ & 0 & $12.5 \%$ \\
\hline “Max AF Use" & $\$ 822 \mathrm{~K}$ & 1,231 & $75 \%$ & 9 & $41.3 \%$ \\
\hline
\end{tabular}

Figure 14: Selected optimization results

\section{Selected Resources}

\section{Federal Fleet Requirements}

http://www1.eere.energy.gov/femp/program/fedfleet requirements.html

Overview of the requirements and mandates for federal fleet vehicles

\section{Fleet Management Resources}

http://wwwl.eere.energy.gov/femp/program/fedfleet resources.html

A list of resources available to help federal agencies manage vehicle fleets and increase the use of alternative fuels

\section{Alternative Fuels and Advanced Vehicles Data Center}

http://www.afdc.energy.gov/afdc/

Provides a wide range of tools for federal fleet management-a couple of these tools are highlighted below

\section{Flexible Fuel Vehicle Cost Calculator}

http://www.afdc.energy.gov/afdc/progs/cost anal.php?0/E85/

All available flexible fuel vehicles are provided in this tool. Select the FFV you are interested in, 
then select a state where E85 is available. You can calculate the cost of driving the selected vehicle, gallons of gasoline saved, and pounds of greenhouse gases saved by fueling with E85.

\section{Alternative Fueling Station Locator}

http://www.afdc.energy.gov/afdc/locator/stations/

Find alternative fueling station locations

\section{EPA Green Vehicle Guide}

http://www.epa.gov/greenvehicles/Index.do;jsessionid=9f852d7c2041982bbf914c676b6103ca72 $\underline{88 \mathrm{~d} 56 \mathrm{e} 0005 \mathrm{c} 566 \mathrm{ce} 4 \mathrm{c} 61 \mathrm{c} 89 \mathrm{~d} 34 \mathrm{c} 338}$

Use this guide to choose the cleanest and most fuel-efficient vehicle that meets your needs. Low emissions and good fuel economy are both important for the environment.

\section{EPA Transportation Tools site}

http://www.epa.gov/climatechange/wycd/tools transportation.html

Includes tools for the nonroad vehicle model, MOBILE model, MOVES model, freight carriers and shipping models, etc. 


\section{Electrical Systems Assessment}

Prior to the final determination of the recommended energy projects, an assessment of the existing electrical system should be conducted. This evaluation will determine whether the site electrical infrastructure is robust enough to accommodate the proposed new energy generation systems. Basic calculations and a working knowledge of the capacity of the existing infrastructure can provide information necessary to determine the feasibility and approximate costs of the recommended energy projects.

Improved energy security is a key goal for net zero energy installations. Building an energy system that can stand independent of the grid is a common method to increase energy security. As part of a NZEI assessment, an analysis of the potential to operate a microgrid independent of the larger electrical grid should be conducted. This analysis should also consider system reliability and fuel source independence.

A basic electrical analysis is the recommended approach for a NZEI assessment. Additionally, more detailed approaches are also described. These more detailed analysis approaches have greater data requirements and may require advanced modeling and simulation software analysis packages. More detailed assessments may need to be performed if technical or policy issues are identified or if more detailed feasibility assessments are desired.

\subsection{Grid-Connected Operations: Impact Assessment}

Under grid-connected operation, the site maintains an electrical connection to the area power system. Generally, the connection to the local grid simplifies analysis by providing a stable voltage and frequency reference.

In rare cases such as sites located on islands, the site may make up a large percentage of system load. In such cases, the impact of the proposed generation projects on the system should be evaluated. In all cases, utility interconnection requirements should be satisfied.

\section{Approach}

A minimum electrical assessment includes a high level screening study to determine whether potential renewable placement will require a major distribution system overhaul. The site should consider whether there is any flexibility with regard to changing existing distribution infrastructure. Some upgrades to secondary equipment such as distribution transformers and cabling will probably be necessary. This assessment should review utility interconnection requirements and help ensure that they are not violated. This assessment level involves simple calculations primarily based on nameplate capacity and basic load and generation data and does not require a distribution system software analysis package; however, if a suitable model of the site distribution system already exists, it may be used to perform the analysis. HOMER may be used to determine the optimal grid-tied hybrid system with distributed generation.

\section{More Detailed Approaches}

Beyond the basic assessment, more detailed analyses may be completed to address specific questions or concerns. A basic static system analysis may be used to answer specific questions or concerns about thermal limits on conductors or voltage regulation requirements, for example. Basic load flow analyses can be run for different load and generation scenarios to evaluate 
system impacts. Software and model representation of the system will be necessary for this type of analysis. Possible distribution system modeling software options include Distributed Engineering Workstation (DEW), SynerGEE, FeederAll, EasyPower, Milsoft WindMil, or ASPEN.

If more detail is required, the next level of detailed analysis includes evaluating voltage stability, rotor angle stability, short circuit analysis, and frequency stability. These studies require very detailed analysis with specific equipment specifications or appropriate generic device models. This level of analysis requires significant resources and would only be performed if warranted by the scale or unique nature of the load profile or proposed generation.

\section{Key Data and Information \\ Distribution System}

- Recommended approach: Single-line diagram, maps of system with conductor sizes, sizing and location of significant loads (including historical peak and minimum load), basic nameplate data for equipment including switches, circuit breakers, transformers, etc.

- More detailed approaches: Data requirements for recommended approach plus detailed drawings/information relevant to the particular study that might include conductor characteristics, cable/line distances, cable/line configurations, voltage regulation equipment and settings, transformer connections, switch positions, etc., plus load characteristics and detailed utility interconnection data. Load information includes type of load (e.g., large motors on the system), static load make up (constant power, current, or impedance), location and behavior of large, active loads, and dynamic load behavior.

\section{Metering and Modeling}

- Recommended approach: Hourly load data from site or substation advanced meters; hourly building or individual load level data is preferred.

- More detailed approaches: Hourly load data from advanced meters by building/load location. If building/load level data is not available, metering should be sufficient to determine hourly load data at major points in the distribution system. Ideally, five years of historical load data at all major buildings should be available; this data should be in hourly increments, if possible. If hourly data is not available, peak and minimum load data should be sufficient. Since metering may need to be installed and allowed to collect data for a period of time, data acquisition should begin as soon as possible in a project cycle. Many sites have distribution system models in use for planning purposes. If a model exists it is very helpful for assessment even if the model is not sufficient for the needs of the project. An existing, validated model can provide a good starting point for analyzing the impacts of new generation on the system. For transient analysis, sub-hourly and sometimes sub-second load data may be necessary. Major loads should be identified and monitored.

\section{Generation}

- Recommended approach: Location, size, connection, and control strategies for existing generation. Data on actual generation use is also desirable including frequency and length of use, cause for outage (if emergency) and loads served (e.g., load shedding scheme). 
- More detailed approaches: Data on existing and proposed generation type and detailed parameters such as governor and exciter types and settings, inertia of rotating machines, impedance data, inverter settings, etc.

\section{Planning Considerations}

- Utility interconnection requirements.

- A summary of extreme loading conditions (either minimum or maximum) and growth scenarios that have potential impact on future planning scenarios.

\subsection{Islanded Microgrid Assessment}

If independence from the grid is important to the installation, then a microgrid assessment should be performed. This analysis should be integrated with the original energy assessment as early in the process as possible.

The site should decide which loads are critical and should be included in the microgrid and the expectations surrounding the operations of the microgrid. To facilitate analysis, critical loads should behave the same (or at least similarly) under the microgrid scenario as they do under the grid connected scenario. Considerations that will be integral to these decisions include load shedding capability/demand response management and existing generation capability for emergency backup.

Another significant issue that needs to be explored is determining if any of the potential renewable resources identified for the installation in the energy assessment can be dispatched (e.g., biomass). If the renewable generation resources that were identified in the initial energy assessment are not dispatchable, some thought must be given to energy storage options and generators.

The output from the microgrid analysis will be identification of critical loads, examination of existing backup power systems, analysis of load profile to determine coincidence between renewable energy and critical load, and a basic overview of potential microgrid operation. Similar to the section above, the recommended approach as well as more detailed approaches are described below.

\section{Recommended Approach}

- Determination of the desired microgrid size, critical loads, and area.

- Analysis of the most economical electric hybrid system with generators, storage, demand response, and renewable energy sources. Modeling can be done with HOMER or other software.

- Overview of the possible dispatch/microgrid control methods. Grid operations utilize dispatch centers that are staffed 24/7 with some remote sensing/dispatching capability. To be affordable, the microgrid must rely more heavily on the remote control capabilities.

- Assessment of the required system changes for a microgrid and their approximate costs. 


\section{More Detailed Approaches}

- Build system models and control schemes for the microgrid. These models can help identify expected upgrades to generation and distribution systems, and identify locations and types of additional distributed generation needed to maintain microgrid power stability and power quality. Modeling can be done with Distributed Engineering Workstation (DEW), SynerGEE, FeederAll, EasyPower, Milsoft WindMil, or other software.

\section{Key Data and Information}

- Recommended approach: Location and size of critical loads to be supplied by the microgrid; location and size of existing backup power systems.

- More detailed approaches: Hourly load profile of critical loads to determine predicted coincidence between renewable energy and critical loads. This match will determine the level of dispatchable generation sources such as diesel generators or energy storage that will be needed. A load shedding schedule or demand response protocol may need to be developed to provide additional options that are cost effective. For more detailed analysis, the variability of the distributed energy sources and their impact on the microgrid stability and power quality should be considered.

\section{Planning Considerations}

- Utilization of the smart microgrid for demand response, and building control system monitoring.

- Security of data from advanced meters and the control system.

Figure 15 shows a sample microgrid design methodology resulting in an RFP. 


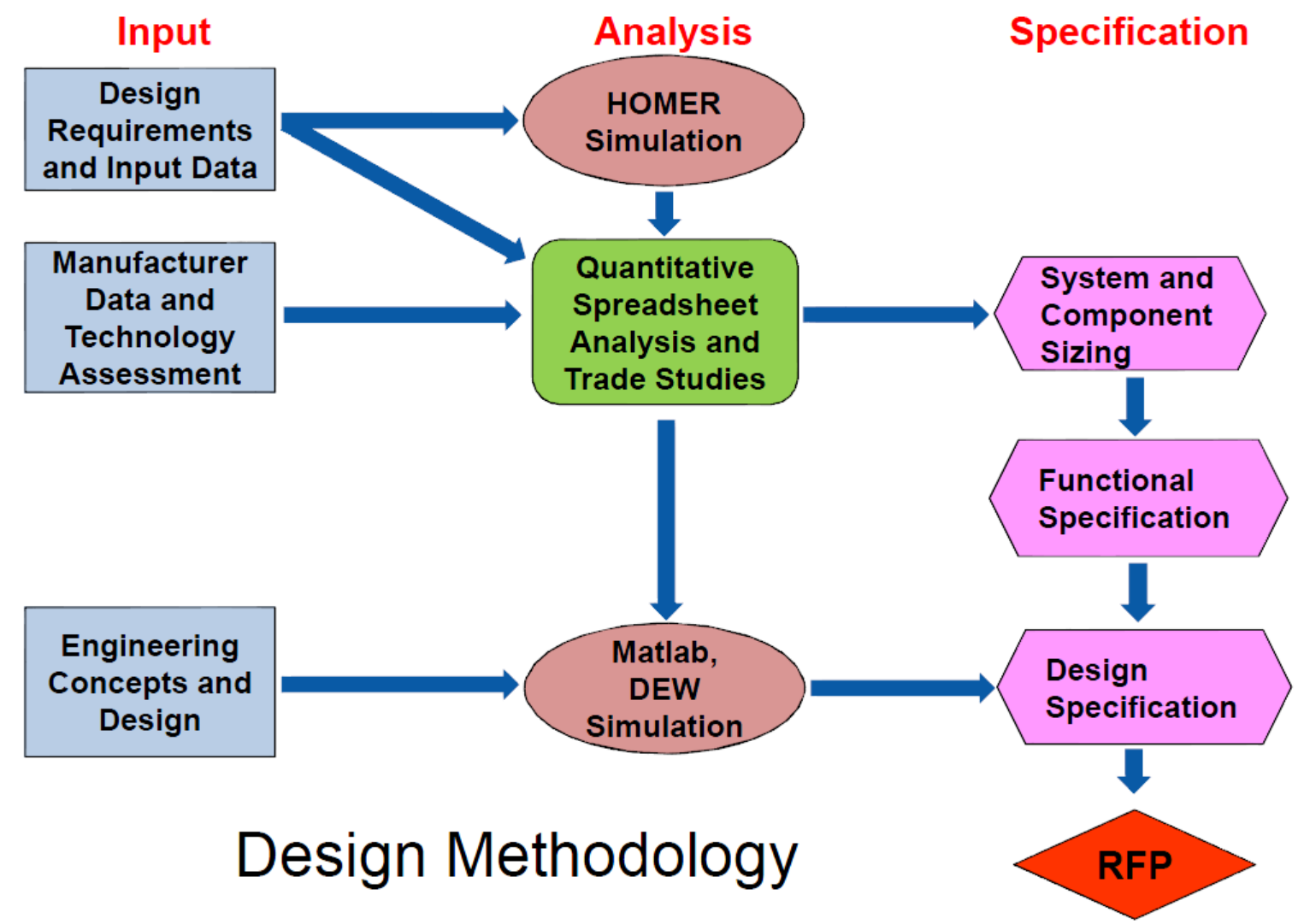

Figure 15: Sample microgrid design methodology ${ }^{18}$

\section{Selected Resources}

The Smart Grid, An Introduction

U.S. Department of Energy, No.DE-AC26-04NT41817, Subtask 560.01.04, http://www.oe.energy.gov/DocumentsandMedia/DOE SG Book Single Pages(1).pdf. Overview of the smart grid and its potential benefits

\section{DOE Smart Grid Resources}

http://www.oe.energy.gov/smartgrid.htm

Portal listing resources for smart grid projects, tools, and information

Distributed Engineering Workstation (DEW)

http://edd-us.com/about.html

Distribution system modeling software

\section{HOMER}

http://www.homerenergy.com/index.asp

Distributed Energy Analysis Tool

\footnotetext{
${ }^{18}$ Bill Kramer, NREL
} 


\section{GridLab-D}

http://www.gridlabd.org/

Power system simulation tool that provides information to users who design and operate electric power transmission and distribution systems

\section{EPRI Smart Grid projects}

http://www.smartgrid.epri.com/DemoProjects.aspx

$R \& D$ projects to demo smart grid technologies

\section{Performing Energy Security Assessments}

http://www1.eere.energy.gov/femp/pdfs/energy_security_guide.pdf

A guide for federal facilities managers on how to perform an energy security assessment 


\section{$9 \quad$ Energy Project and Implementation Recommendations}

The overall goal of a net zero energy assessment is to recommend an optimal energy strategy that will support the installation's energy goals. In determining this strategy, consideration must be given not only to the net zero energy goal but also to factors including mission compatibility, energy security, project economics, military agency goals, federal mandates, site resources, funding, and staff availability. This last step of project assessment prior to implementation action should address project selection, the implementation approach, and a basic financial analysis at a sufficient level of detail to enable decision makers to proceed with project implementation.

\section{Approach}

Project Selection

- A list of recommended projects is developed based on performance, suitability, and commercial availability of the technology, and on satisfaction of the nontechnical criteria noted above: mission compatibility, energy security, project economics, military agency goals, federal mandates, site resources, funding, and staff availability.

- Each project should be screened for viability using a set of criteria covering critical aspects of project development that may prove fatal to a proposed project, or "deal killers." An example set of criteria is given in the next section.

- Compare renewable energy and energy efficiency improvements to the energy baseline to determine progress toward net zero energy installation status. Estimate GHG reduction potential by comparing energy project savings to the GHG baseline.

- Develop preliminary cost estimates for the recommended energy efficiency and renewable energy technologies.

- Determine a recommended time-phased implementation plan for installation energy projects.

\section{Implementation Approach}

- Candidate implementation approaches are identified, including project structuring and financing options.

- For the identified options, compare factors such as availability of incentives, ownership issues, O\&M, financing rates, and potential partners.

- An appropriate approach is selected for each project, which may be an iterative process.

\section{Basic Financial Analysis}

- Develop a business-as-usual case for projected energy costs based on the existing energy system.

- Estimate the net energy savings and capital cost of the recommended projects.

- Conduct a financial analysis, determining the net present value, savings-to-investment ratio and other financial metrics for the recommended projects. Develop a sensitivity analysis around selected key parameters to address the uncertainty and variability of the financial assumptions. 
- Compare the recommended energy projects with the business-as-usual case to validate that the established economic criteria are being met.

\section{Key Data and Information}

\section{Project Selection}

- Performance, commercial availability, and cost of selected technologies.

- Consistency of projects with criteria for mission compatibility, energy security, military service goals, federal mandates, site resources, funding, and staff availability.

- The goal of the NZEI assessment is to provide an optimal energy strategy for an installation that informs project implementation. However, a NZEI assessment will not typically provide sufficient detail for the implementation of all recommended energy projects; the projects should be screened early on for issues that may prohibit implementation, or "deal-killers". A seven-element framework for this purpose, developed at NREL and summarized by the acronym SROPTTC, is outlined below. The specific considerations related to each of the key areas will vary on a project-by-project basis; sample considerations are provided.

○ Site:

- Where will the project be located?

- How will the developer be given legal control?

- Current utility usage and rates?

- Proximity to grid and thermal hosts?

- Allowable use and zoning?

○ Resource:

- What is the wind, solar, and geothermal resource potential?

- How much waste and biomass is available and what does it cost?

○ Off-take:

- Who will buy the power and/or thermal energy?

- What are the interconnection options and requirements?

- Will the installation export power to the grid?

- Is the installation willing to enter into a long term contract (20 years)?

- Does the installation have the authority to enter into a long term contract?

- Who will develop a detailed project description and process flow diagrams, and estimate system size and annual generation $(\mathrm{MWh} / \mathrm{yr})$ ?

- What is the levelized cost of energy?

o Permits:

- What is the process for National Environmental Policy Act (NEPA) review? Is an environmental assessment or environmental impact statement required? 
- Who has local jurisdictional authority?

- What are the emissions limits for criteria pollutants?

- Who will compile a list of all the permits needed for various areas such as solid waste, air, construction, and operations - state, local, and federal?

- Timeframe - how long does the process take?

○ Technology:

- Technical performance goals (MWh per year, time of delivery, cost)?

- Do permit limits influence technology selection?

- Performance guarantees, warranties?

- Commercial history of technology?

- Willingness to take technology risk?

- Is O\&M required and who is responsible?

- Can the technology be financed?

- Will the installation be meeting federal plus military energy and GHG mandates?

○ Team:

- Who is the on-site champion?

- What resources are available to assist with the development process?

- Who is the technology partner/developer? What are their qualifications (years experience, number of successful similar projects)?

- Who will write and review RFPs and monitor construction?

○ Capital:

- What ownership structures are acceptable to government and industry?

- What are the applicable incentive programs and how do these affect implementation choices?

- Is this a bankable project?

- Is the project eligible for loan guarantees or tax credits?

- Will the agency sell or keep the RECs?

\section{Implementation Approach}

- Gather information on the available implementation options for an installation. Typical implementation options for a military installation will include: ESPCs, UESCs, power purchase agreements (PPA), enhanced use leases (EUL), energy joint ventures (EJV), and appropriated funds. Choosing the appropriate implementation option for each installation will require analysis and additional information. Sample considerations include project size, land availability and use, preferred partners (private industry, utilities, other government agencies), and sources of appropriated funds. 


\section{Basic Financial Analysis}

- Vendor quotes, recently published data, or various software packages to estimate the cost of renewable energy and energy efficiency technologies and their operation.

- The availability of incentives for the base or third-party developer.

- Discount rates, debt to equity ratios, PPA prices, ESPC costs, and other financial assumptions will be needed to evaluate cost savings and returns.

An overview of the project development process is shown below. The NZEI assessment process is particularly helpful in numerous areas related to this process including: helping an installation identify problems or opportunities for energy projects; conducting pre-development work, analysis, and planning; as well as investigating the next steps to transition from planning (information) to implementation (action). This is a cyclical process because it will usually take many projects to transition an installation toward net zero energy status.

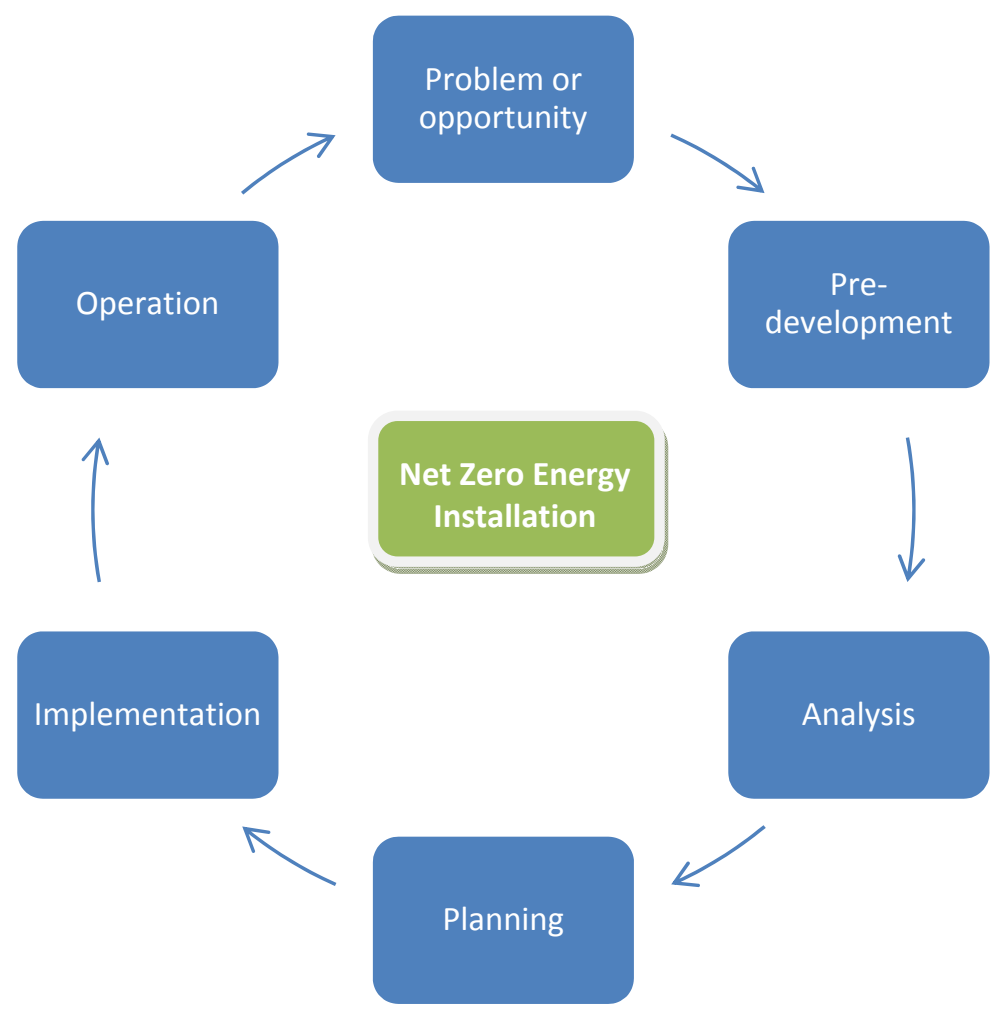

Figure 16: Project development process overview

\section{Selected Resources}

Financing Mechanisms

http://wwwl.eere.energy.gov/femp/financing/mechanisms.html

FEMP overview and information on common financing mechanisms for federal projects 


\section{Incentive Availability Summary}

http://www.dsireusa.org/

Database listing the incentive programs available for renewable energy and energy efficiency

Super ESPC Awarded Delivery Order Summary

http://www1.eere.energy.gov/femp/pdfs/do awardedcontracts.pdf

Database of information regarding awarded ESPC contacts - could be useful to determine

approximate costs

Evaluation of Federal Energy Savings Performance Contracting-Methodology for Comparing Processes and Costs of ESPC and Appropriations Funded Energy Projects Hughes, Shonder, Sharp, and Madgett; Oak Ridge National Laboratory; 2003; ORNL/TM2002/150, http://www.ornl.gov/sci/ees/etsd/btric/pdfs/com espc lcc.pdf.

Compares the differences in costs for ESPC and appropriations funded projects to allow for informed decision making on financial mechanisms

\section{Comparing Life Cycle Cost of ESPC and Appropriations Funded Projects: An Update to} the 2002 Report

Shonder, Hughes, and Atkin; Oak Ridge National Laboratory; 2006; ORNL/TM-2006/138, http://www.ornl.gov/sci/ees/etsd/btric/pdfs/com_espc lcc 2006update.pdf.

An update to the previous report comparing ESPC and appropriations funded project costs

NIST Energy Price Indexes and Discount Factors, 2009

http://www1.eere.energy.gov/femp/pdfs/ashb09.pdf

Information on estimated future energy prices and discount factors that can be used for financial analysis

The California Biomass Collaborative Cost Calculator

http://biomass.ucdavis.edu/calculator.html

Cost calculation tools for a variety of biomass energy projects and financial arrangements 


\section{Summary}

Analyzing an installation for net zero energy potential provides a disciplined way to identify an energy strategy tailored to the needs of specific military installations. A systematic net zero energy assessment is a tool that should incorporate other site-specific considerations such as security, costs, and federal goals into a single assessment. The ability for a military installation to become a net zero energy installation will depend on many factors, and may not be practically achievable. This template is intended as an introduction to analyzing an installation for net zero energy potential as a step toward implementing an optimal energy strategy.

The ultimate goal of any energy project assessment is to inform the successful implementation of energy saving and renewable energy projects. Assessments should focus on realistic projects that have a high probability of implementation. Successful implementation of energy projects at an installation will require a dynamic and collaborative approach; ideally a project team should be developed to implement the recommended projects. As projects are implemented, the net zero energy assessment presents a benchmark by which to measure progress in reducing energy demand and increasing energy self-sufficiency by reliance on local renewable resources. When finished with this assessment the installation should have a clear understanding of the opportunities for future energy projects, as well as the process and approximate costs required to fully implement projects. 


\section{NOTICE}

This report was prepared as an account of work sponsored by an agency of the United States government. Neither the United States government nor any agency thereof, nor any of their employees, makes any warranty, express or implied, or assumes any legal liability or responsibility for the accuracy, completeness, or usefulness of any information, apparatus, product, or process disclosed, or represents that its use would not infringe privately owned rights. Reference herein to any specific commercial product, process, or service by trade name, trademark, manufacturer, or otherwise does not necessarily constitute or imply its endorsement, recommendation, or favoring by the United States government or any agency thereof. The views and opinions of authors expressed herein do not necessarily state or reflect those of the United States government or any agency thereof.

Available electronically at http://www.osti.gov/bridge

Available for a processing fee to U.S. Department of Energy and its contractors, in paper, from:

U.S. Department of Energy

Office of Scientific and Technical Information

P.O. Box 62

Oak Ridge, TN 37831-0062

phone: 865.576 .8401

fax: 865.576 .5728

email: mailto:reports@adonis.osti.gov

Available for sale to the public, in paper, from:

U.S. Department of Commerce

National Technical Information Service

5285 Port Royal Road

Springfield, VA 22161

phone: 800.553 .6847

fax: 703.605.6900

email: orders@ntis.fedworld.gov

online ordering: http://www.ntis.gov/ordering.htm 


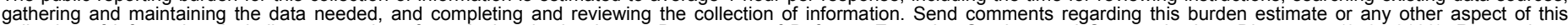

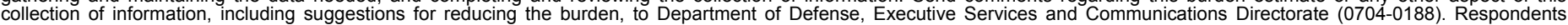

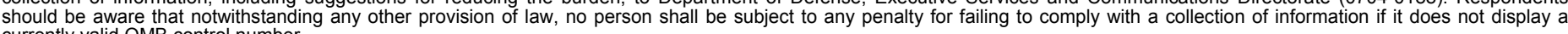

PLEASE DO NOT RETURN YOUR FORM TO THE ABOVE ORGANIZATION.
1. REPORT DATE (DD-MM-YYYY) August 2010
4. TITLE AND SUBTITLE
Net Zero Energy Military Installations: A Guide to Assessment and Planning

6. AUTHOR(S)

S. Booth, J. Barnett, K. Burman, J. Hambrick, and R. Westby
3. DATES COVERED (From - To)

5a. CONTRACT NUMBER

DE-AC36-08-GO28308

5b. GRANT NUMBER 5d. PROJECT NUMBER

NREL/TP-7A2-48876

5e. TASK NUMBER

IDOD.1010

5f. WORK UNIT NUMBER
7. PERFORMING ORGANIZATION NAME(S) AND ADDRESS(ES)

National Renewable Energy Laboratory

1617 Cole Blvd.

Golden, CO 80401-3393
8. PERFORMING ORGANIZATION REPORT NUMBER

NREL/TP-7A2-48876

9. SPONSORING/MONITORING AGENCY NAME(S) AND ADDRESS(ES)

10. SPONSOR/MONITOR'S ACRONYM(S) NREL

11. SPONSORING/MONITORING AGENCY REPORT NUMBER

\section{DISTRIBUTION AVAILABILITY STATEMENT}

National Technical Information Service

U.S. Department of Commerce

5285 Port Royal Road

Springfield, VA 22161

\section{SUPPLEMENTARY NOTES}

\section{ABSTRACT (Maximum 200 Words)}

The U.S. Department of Defense (DoD) recognizes the strategic importance of energy to its mission, and is working to reduce energy consumption and enhance energy self-sufficiency by drawing on local clean energy sources. A joint initiative formed between DoD and the U.S. Department of Energy (DOE) in 2008 to address military energy use led to a task force to examine the potential for net zero energy military installations, which would produce as much energy on site as they consume in buildings, facilities, and fleet vehicles. This report presents an assessment and planning process to examine military installations for net zero energy potential. Net Zero Energy Installation Assessment (NZEIA) presents a systematic framework to analyze energy projects at installations while balancing other site priorities such as mission, cost, and security.

\section{SUBJECT TERMS}

U.S. Department of Defense; DoD; reduce energy consumption; energy self-sufficiency; local clean energy sources; U.S. Department of Energy; DOE; military energy use; net zero energy military installations; energy assessment and planning process; Net Zero Energy Installation Assessment; NZEIA; islanded microgrid operations; National Renewable Energy Laboratory; NREL

\begin{tabular}{|c|c|c|c|c|}
\hline \multicolumn{3}{|c|}{ 16. SECURITY CLASSIFICATION OF: } & \multirow{2}{*}{$\begin{array}{l}\text { 17. LIMITATION } \\
\text { OF ABSTRACT } \\
\text { UL }\end{array}$} & \multirow{2}{*}{$\begin{array}{ll}\text { 18. } & \text { NUMBER } \\
\text { OF PAGES }\end{array}$} \\
\hline $\begin{array}{l}\text { a. REPORT } \\
\text { Unclassified }\end{array}$ & $\begin{array}{l}\text { b. ABSTRACT } \\
\text { Unclassified }\end{array}$ & $\begin{array}{l}\text { c. THIS PAGE } \\
\text { Unclassified }\end{array}$ & & \\
\hline
\end{tabular}

19a. NAME OF RESPONSIBLE PERSON

19b. TELEPHONE NUMBER (Include area code) 